OPEN ACCESS

Edited by:

Shalin Naik,

Walter and Eliza Hall Institute,

Australia

Reviewed by:

Kristen J. Radford,

University of Queensland, Australia

Simon Yona,

University College London, UK

*Correspondence:

Muzlifah Haniffa,

Human Dendritic Cell Laboratory,

Institute of Cellular Medicine, The

Medical School, Newcastle

University, Framlington Place, Newcastle upon Tyne NE2 4HH, UK

m.a.haniffa@ncl.ac.uk

Specialty section:

This article was submitted to Antigen Presenting Cell Biology, a section of the journal Frontiers in Immunology

Received: 11 May 2015 Accepted: 12 June 2015 Published: 25 June 2015

Citation:

Reynolds G and Haniffa M (2015) Human and mouse mononuclear

phagocyte networks: a tale of two

species?

Front. Immunol. 6:330.

doi: 10.3389/fimmu.2015.00330

\section{Human and mouse mononuclear phagocyte networks: a tale of two species?}

\author{
Gary Reynolds ${ }^{1,2}$ and Muzlifah Haniffa ${ }^{1 *}$ \\ ${ }^{1}$ Human Dendritic Cell Laboratory, Institute of Cellular Medicine, Newcastle University, Newcastle upon Tyne, UK, \\ ${ }^{2}$ Musculoskeletal Research Group, Institute of Cellular Medicine, Newcastle University, Newcastle upon Tyne, UK
}

Dendritic cells (DCs), monocytes, and macrophages are a heterogeneous population of mononuclear phagocytes that are involved in antigen processing and presentation to initiate and regulate immune responses to pathogens, vaccines, tumor, and tolerance to self. In addition to their afferent sentinel function, DCs and macrophages are also critical as effectors and coordinators of inflammation and homeostasis in peripheral tissues. Harnessing DCs and macrophages for therapeutic purposes has major implications for infectious disease, vaccination, transplantation, tolerance induction, inflammation, and cancer immunotherapy. There has been a paradigm shift in our understanding of the developmental origin and function of the cellular constituents of the mononuclear phagocyte system. Significant progress has been made in tandem in both human and mouse mononuclear phagocyte biology. This progress has been accelerated by comparative biology analysis between mouse and human, which has proved to be an exceptionally fruitful strategy to harmonize findings across species. Such analyses have provided unexpected insights and facilitated productive reciprocal and iterative processes to inform our understanding of human and mouse mononuclear phagocytes. In this review, we discuss the strategies, power, and utility of comparative biology approaches to integrate recent advances in human and mouse mononuclear phagocyte biology and its potential to drive forward clinical translation of this knowledge. We also present a functional framework on the parallel organization of human and mouse mononuclear phagocyte networks.

Keywords: mononuclear phagocyte system, dendritic cells, macrophages, monocytes, comparative genomics

\section{Introduction}

The mononuclear phagocyte system (MPS) is a branch of the immune system comprising dendritic cells (DCs), macrophages, and monocytes (1-3). The many functions of the MPS include tissue maintenance and healing, innate immunity and pathogen clearance, and the induction of adaptive immune responses (1-3). Manipulating these functions could lead to clinical benefit, such as modulating DCs to develop antigen-specific anti-tumor immunity or suppressing peripheral autoreactive $\mathrm{T}$ cell responses in autoimmunity $(4,5)$. Several factors need to be considered in designing immunotherapy targeting the MPS, including cellular or pathway target choice and the relevant disease and tissue context. Diversity and plasticity of the MPS, two core features that are paramount for directing the quantity and quality of specific immune responses, have frustrated attempts to develop successful focused therapies. The additional variable of local tissue environment, which also heavily influences the 
composition and function of resident and infiltrating mononuclear phagocytes (MPs), also requires careful consideration (1-3).

The MPS was conceived in the 1960s by van Furth to encompass a family of phagocytic mononuclear leukocytes regarded as functional variations of monocytes (6). DCs were embraced as members of the MPS several years later (7). The revolutionary discovery that human monocytes and $\mathrm{CD} 34^{+}$hematopoietic stem cells (HSCs) could be differentiated into DC (mo-DC) and macrophage-like (mo-Mac) cells provided a convenient in vitro model to study human MP biology $(8-10)$. However, murine studies have demonstrated the independence of many DCs, macrophages, and Langerhans cells (LCs) from blood monocytes questioning the accuracy of human in vitro monocyte-derived cells in recapitulating in vivo populations (11-16). Conventional DCs arise from HSCs along a lineage that does not go through a monocyte stage and are dependent on the growth factor receptor FLT3 (11). In contrast, the majority of tissue macrophages arise from prenatally seeded precursors that can survive into adulthood and are dependent on CSF1-R (12-16).

The constituents of MPS share overlapping surface markers, which poses a challenge in parsing functionally distinct populations. A rewarding approach to unravel this complexity has been comparative biology analysis (17-28). In essence, comparative biology relies on the concept that core developmental programs and functions such as differential CD4 and CD8 T cell priming, cross-presentation, migration, and cytokine production are likely to be non-redundant and conserved between species. In support of this, around $99 \%$ of murine genes have human analogs and around $96 \%$ are syntenic, despite the two species having 80 million years of divergent evolution (29). Comparative transcriptomic mapping has revealed conserved gene expression profiles in the two species allowing parallels to be drawn between DC and macrophage subsets (17-28). This approach places comparative analysis as the central fulcrum facilitating the integration of fundamental immunology to fertilize clinical translational strands (Figure 1). Integrating this workflow with

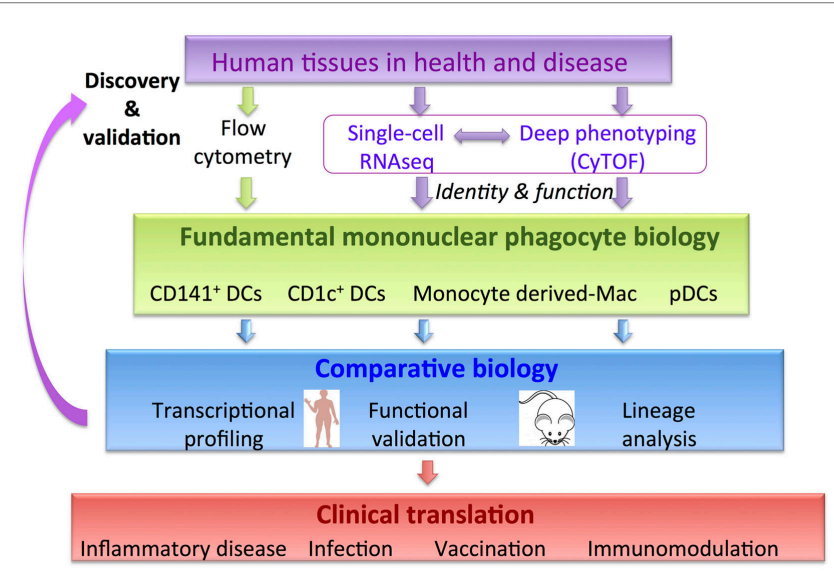

FIGURE 1 | Comparative biology is a validation and discovery tool to pull-through fundamental knowledge in MPS biology to clinical translation. Incorporation of new genomics and proteomics methodologies will accelerate discovery. cutting-edge technologies including single-cell genomics and proteomics approaches has the potential to accelerate discovery in basic MP biology and its clinical applicability (Figure 1). Comparative biology has revealed further insights into the origin and function of human and mouse mononuclear phagocyte populations (17-28) and generated new hypotheses to be tested in both species.

The concept of functional specialization as an inherent property imprinted by MP ontogeny and tissue anatomy has been well demonstrated in many murine studies [reviewed in Ref. $(1,3,30)$ ]. However, the MPS possesses an additional layer of complexity in the form of dynamic mobility, plasticity, and adaptability to tissue/local microenvironment both in steady state and in inflammation $(1,3,31)$. These issues have been particularly difficult to dissect in human, where the temporal resolution to observe these kinetics is constrained by snapshot analysis during inflammation and disease without adequate recourse to their onset and evolution (Figure 2). Snapshot observations during inflammation may be confounded by temporal variations in MPS composition and function resulting in highly variable biological data. This variability may account for the biological noise inherently observed with outbred humans in contrast to inbred mice in specific pathogen free (SPF) facilities.

Mononuclear phagocytes and their progenitors are in dynamic equilibrium between peripheral tissue, blood, and bone marrow $(1,3,31,32)$. The distinction between MPs within peripheral interstitial tissue and blood can be difficult to establish in highly vascularized organs such as liver and spleen, where large sinusoids are present adjacent to discontinuous endothelial lining that enables greater mobility of leukocytes within these organs. In addition, inflammatory perturbations affect the dynamic equilibrium between tissue, blood, and bone marrow compartments favoring the relative expansion and egress of specific lineages in response to distinct stimuli (33-35). Expansion of monocyte-derived cells dominates the response to inflammatory stimuli in tissue but little is known regarding their fate upon resolution of inflammation (35). Peripheral tissue DCs migrate to the lymph node where they mediate their potent functions upon inflammatory stimuli. Whether they play a prominent role in local tissue immune regulation and how migratory DCs are repopulated during inflammation and its resolution has been poorly characterized.

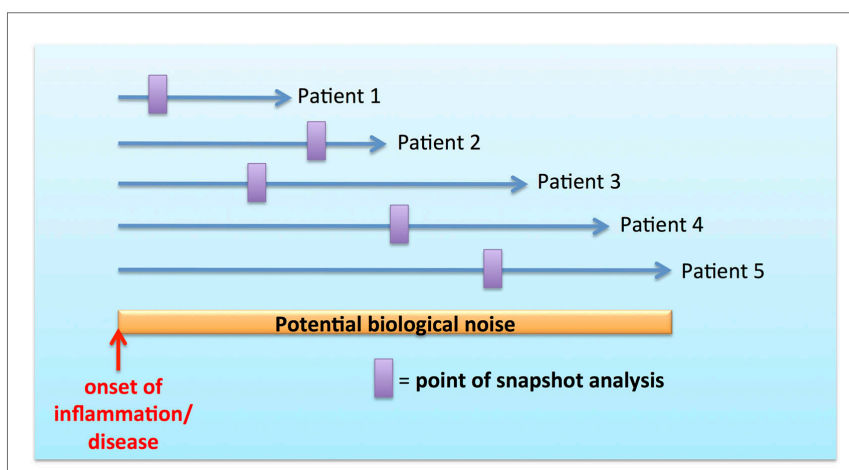

FIGURE 2 | Biological noise with snapshot analysis during temporal course of inflammation and disease. 


\section{Comparative Biology to Interrogate Human and Mouse MP Networks}

Identifying homology between mice and humans in other hematopoietic cells such as T and B cells has been relatively simple at phenotype and practical levels because of shared lymphocyte surface markers (CD3/CD4/CD8 and CD19, respectively) as well as the relative ease of isolating lymphocytes, which form $90 \%$ of human peripheral blood mononuclear cells (c.f. $<1 \%$ being DCs). Nevertheless, there are functional differences in lymphocytes between the two species, such as differentiation requirements for IL-17 (36) and GM-CSF $(37,38)$ secreting CD4 $4^{+} \mathrm{T}$ cells, the specificity of granzyme and FOXP3 expression to define natural Tregs (39), the distinct classes of immunoglobulin (40) and human CD1a, 1b, and 1c-restricted responses to lipid molecules (41). Unfortunately, components of the human and mouse MPS lack overlapping phenotypic markers, hampering initial progress in identifying homologous populations between species.

A range of -omics technologies such as transcriptomics, metabolomics, proteomics, and epigenomics could potentially be employed to assess proximity between species. Of these approaches, transcriptomics is technically most tractable and generates enough complexity to achieve good definition between populations ( $n$-dimensions where $n$ is the number of genes analyzed) (42, 43). Transcriptome-based comparison of various hematopoietic lineages between human and mouse shows broad conservation but also highlighted specific differences and transcriptional divergence due to gene duplication (43).

\section{Transcriptomics}

The hypothesis underlying comparative transcriptomics is that the identified MP populations were present in a shared ancestor and that these same subsets are present in modern animals. Furthermore, despite divergent evolution over time, cells from each subset will have a conserved transcriptomic signature similar to that of its equivalent in the other species. Two approaches are generally used to measuring this similarity: (1) unsupervised hierarchical clustering and principal component analysis (PCA), which assigns samples a point in $n$-dimensional space ( $n$ corresponding to the number of genes analyzed) and applying a distance metric with greater proximity suggesting a developmental relationship, or (2) supervised assessment of defined transcriptome signature enrichment between populations of interest exemplified by gene set enrichment analysis (GSEA) (44) and its later variations (45).

In hierarchical clustering, the Euclidean distance is calculated between samples. In PCA, the same Euclidean metric is used after the $n$-dimensional data are projected on to the two or three dimensions over which the most variation occurs. This approach has the disadvantages inherent in using large sets of gene data, large number of variables/genes, and high inter-sample variability when testing a limited number of samples. The consistent finding that tissue-specific genes predominate in DC microarray transcriptomes highlights the first point. As a result, microarray data of DC subsets from the same tissue tend to cluster together rather than with their equivalent in blood or another tissue (46). This can be corrected for by techniques such as excluding genes that are differentially expressed between pooled cells from each tissue (and classifying these "tissue-specific") $(23,26)$ or through using an abbreviated gene panel that is enriched for genes that are known to give good definition between DC subsets (17). An important corollary of this finding is that, while the relative contribution of ontogeny and environment to DC function remains to be determined, the list of genes that define ontogeny is a small fraction of the genes that are modulated by the environment and highlights a potential drawback of using blood DCs as a proxy for tissue DCs.

The use of GSEA derives from large-scale microarray data in which it was recognized that groups of co-regulated functionally linked genes may be more relevant than the few genes that are most significantly differentially regulated but functionally unrelated. This approach is dependent upon an a priori understanding of gene function and this can introduce bias. When GSEA has been used in aligning DC subsets between species, a "query signature" is produced that defines the subset of interest. Samples in the test population can then be interrogated for whether they are enriched for this query signature. The underlying analysis is based on the non-parametric goodness-of-fit Kolmogorov-Smirnov test statistic with the reference probability distribution that of the query signature. GSEA and its later variant connectivity map analysis (CMAP) have been successfully used to identify homologous MP populations between species and the developmental origin of human inflammatory DCs $(17,23,25,26,47)$. Steady state homologous MP populations in human and mouse blood, lymph node, and peripheral tissues are illustrated in Figure 3.

Most transcriptomics studies thus far on MPs have involved ensemble or bulk-population analysis. This introduces an inherent bias, as cell populations have to be defined a priori based on expression of specific markers. More recently, the application of single-cell RNA-sequencing (sc-RNA-Seq) with unbiased analysis potential has been successfully used to interrogate cellular heterogeneity to

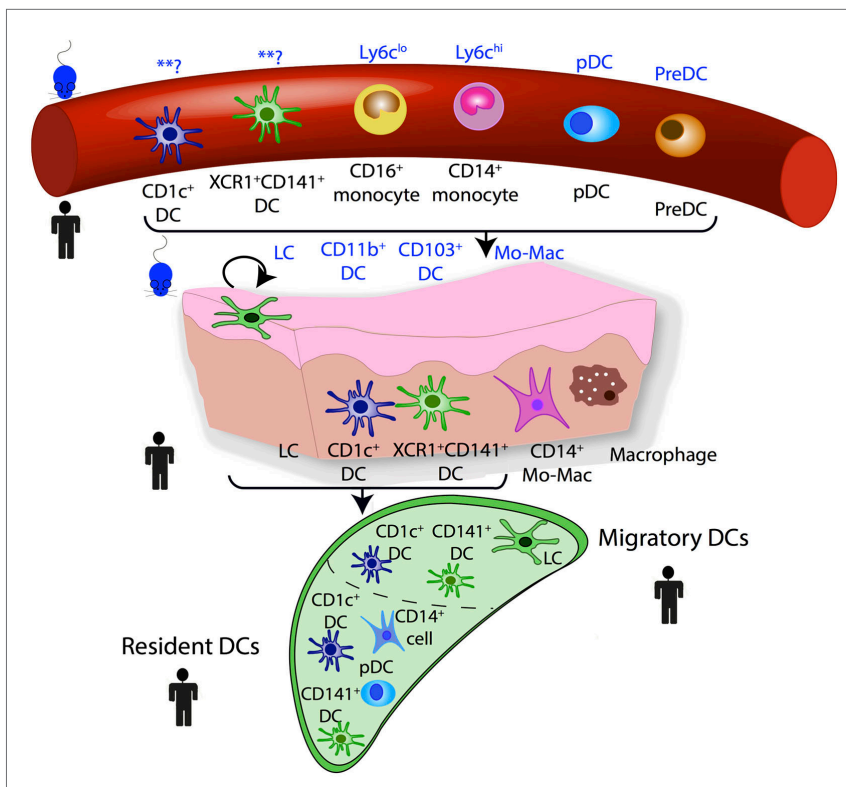

FIGURE 3 | Human and mouse mononuclear phagocyte networks. ${ }^{\star \star}$ ? denotes uncertain murine homologs. 
uncover new cell populations, functional immune states, and to establish cellular lineage hierarchies and lymphocyte differentiation programs (48-53). These technical advances combined with novel computational approaches have the potential to revolutionize our understanding of MPS biology by unraveling predicted and unexpected functional heterogeneity, which underpins the dynamic repertoire of our immune system in health and disease.

\section{Proteomics}

Proteomics analysis has revealed differences in viral sensing pathways between murine splenic DC subsets (54) and identified the murine common monocyte progenitor (cMOP), an intermediate cell-type between the monocyte/macrophage and DC precursor (MDP) and monocyte (55). However, current large-scale proteomics approaches require high cell numbers for robust analysis and are impractical for rare populations, especially from limited human tissue material. Protein expression on a more limited scale has been the mainstay of conventional flow cytometry to define populations and assess MP functions at single-cell resolution. Although the number of parameters that can be analyzed simultaneously is limited (17-18 parameters using commercial instruments), the application of new unbiased probabilistic analysis to define populations could reveal new insights to MP heterogeneity (56). Mass cytometry (CyTOF) provides additional parameters (up to 100) and combined with unbiased population assignment has enormous discovery potential. This combined analysis on mouse myeloid cell populations has revealed far greater population heterogeneity than previously appreciated (57).

\section{Functional Validation}

Comparative functional analysis between mouse and human MPs has resulted in variable findings [reviewed in Ref. $(30,58)]$. It is unknown if this is due to true biological differences or experimental factors which are not comparable within and between species, including the common use of murine in vivo models in contrast to human in vitro assays to assess MP functions. Conserved functions are detailed in Figure 4.

\section{Lineage Analysis}

The power and utility of comparative biology to identify homologous MP populations is beginning to be applied to MP lineage analysis. The recent identification of the successive downstream progenies of human MDP; the Common DC precursor (CDP) and precursor of myeloid DCs (pre-cDCs) exploited the conserved dependency on growth factors and cytokines between human and mouse DC precursors $(27,28)$. Similarly, comparative analysis suggested the monocyte-origin of human dermal CD14 ${ }^{+}$cells (25) and inflammatory DCs (47). The preservation of LCs and dermal macrophages in GATA2 and biallelic IRF8 deficiencies show that they are bone marrow independent in the steady state and similar to their murine counterparts, also arise from prenatally seeded precursors $(59,60)$.

\section{DC, Monocyte, and Macrophage Subsets in Mice and Humans}

This approach of using ontogeny and by extension transcription factor dependence to define MPS populations was formalized

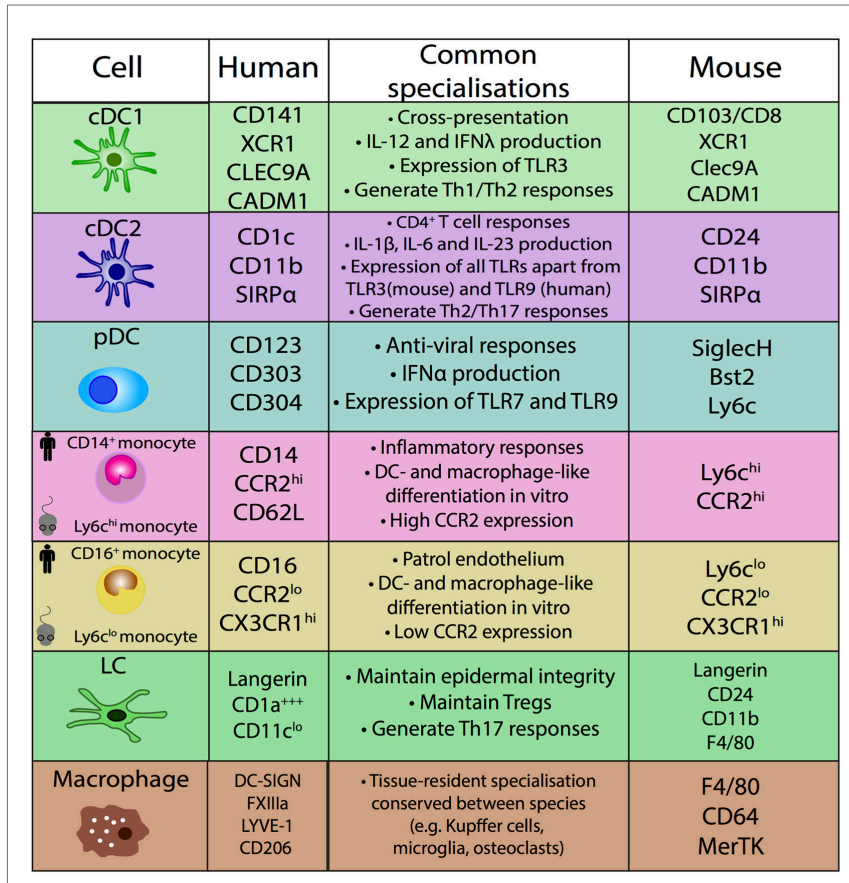

FIGURE 4 | Conserved specializations between human and mouse mononuclear phagocytes

recently in a proposed nomenclature (61). In this scheme, four adult HSC-derived MP populations are described in mice: two conventional/classical DC subsets ( $\mathrm{CDC} 1$ and $\mathrm{cDC} 2)$, plasmacytoid DCs (pDCs), and monocyte-derived cells (61). Both cDCs and pDCs are derived from murine $\operatorname{CDP}(62,63)$. The CDP-derived cells are defined by their dependence on specific transcription factors (TFs): cDC1 are Batf3-dependent, cDC2 are Irf4-dependent, and pDC are E2-2-dependent (61). This definition is unambiguous and avoids using surface markers that can vary between tissues and in inflammation. While the ontogeny approach aids definition of murine populations, it cannot be easily transferred to human DC nomenclature, due to inherent logistical difficulties of human ontogeny studies. However, with the aid of comparative biology approaches, homologous populations between human and mouse MP subsets can be identified and inferences between species on ontogeny and function can be made (Figures 3 and 4).

\section{CDC1}

\section{Phenotype}

This subset is identified in mouse by the expression of CD8 $\alpha$ in the spleen and CD103 in non-lymphoid tissues (NLT). Its human equivalent in blood and NLT were initially defined by their high expression of CD141 (thrombomodulin, BDCA-3) (19-23). However, this antigen can be upregulated on blood monocytes and expressed promiscuously by other DC subsets in human tissue (23). The cell adhesion molecule CADM1 (NECL2), C-type lectin, CLEC9A (which recognizes damaged cells), and the chemokine receptor XCR1 are expressed on human and mouse $\mathrm{CDC1}$ (19, 22, 64-66). However, CADM1 expression is not restricted to leukocytes and CLEC9A is also expressed on murine DC precursors 
$(67,68)$. Although $\mathrm{cDC} 1$ is the only leukocyte expressing XCR1, a commercial antibody against it is currently unavailable. Notably, langerin is expressed on murine but not human $\operatorname{cDC1}(23,69,70)$.

\section{Homology}

Homology between human (XCR $\left.1^{+} \mathrm{CD} 141^{+} \mathrm{DCs}\right)$ and mouse $\left(\mathrm{CD}^{+} / \mathrm{CD} 103^{+}\right) \mathrm{cDC} 1$ was demonstrated by comparative transcriptomics, phenotype, and functional analyses (17, 19-21, 23, 71). Furthermore, blood and skin CD $141^{+}$DCs cluster together separately from $\mathrm{CD} 1 \mathrm{c}^{+} \mathrm{DCs}, \mathrm{CD} 14^{+}$and $\mathrm{CD} 16^{+}$monocytes, and pDCs, suggesting that skin $\mathrm{XCR} 1^{+} \mathrm{CD} 141^{+} \mathrm{DCs}$ are the tissue equivalents of blood XCR1 $1^{+} \mathrm{CD} 141^{+}$DCs (23).

\section{Transcription Factors}

In addition to Batf3 (72), murine $\mathrm{CDC} 1$ differentiation requires Irf8 (73), Id2 (74, 75), and NFIL3 (76). In human, shRNA knockdown of BATF3 in cord blood HSCs inhibits their differentiation into $\mathrm{CDC1}$ in vitro (22). However, $\mathrm{CDC} 1$ were detectable in humanized mice reconstituted with BATF3 knockdown CD $34^{+}$HSCs (22). A possible explanation for this seeming contradiction was shown in mice, where in inflammatory conditions (specifically in the presence of IL-12), other members of the Batf family of TFs appear to be able to compensate for loss of Batf3 (77). ID2 mRNA is expressed at low amounts in human $\mathrm{CD} 34^{+}$HSCs but upregulated during DC differentiation in the presence of GM-CSF and IL-4 (74). Its role is potentially in suppressing B cell differentiation from a common precursor. Definitive evidence for the requirement of ID2 and NFIL3 in CDC1 development in humans is lacking and highlights the potential difficulties of translating TF-based definitions of DC subsets from mice to humans.

\section{Function}

The $\mathrm{cDC} 1$ subset is thought to be able to efficiently prime $\mathrm{CD} 8^{+} \mathrm{T}$ cells through functional specializations such as cross-presentation of antigens and the production of IL- $12 \mathrm{p} 70$ (78-80). This process is important in the induction of tumor immunity and the control of viral and bacterial infections when DCs are not the malignant cells or directly infected. The expression of Clec9A and XCR1 by both murine and human $\mathrm{CDC} 1 \mathrm{~s}$ supports this notion. $\mathrm{cDC} 1 \mathrm{~s}$ express a more limited TLR profile than CDC2s with high expression of TLR3 and TLR10 but without TLR $4,-5,-7$ and $-9(54,81)$. TLR3 senses viral dsRNA but the role of TLR10 is currently unknown. Human cDC1s do not produce large amounts of IL-12p70 in response to TLR ligands alone but do following the combination of TLR ligands and CD40-CD40L signaling through activated T cells (71), in common with the finding in mice (82). IFN- $\lambda$ is produced by murine and human $\mathrm{CDC} 1$ upon stimulation with the TLR3 agonist, poly I:C (83).

Murine $\mathrm{cDC} 1 \mathrm{~s}$ have an advantage over other subsets at crosspresentation of antigens by being able to (1) maintain optimal phagosomal $\mathrm{pH}$ for antigen processing (84) and (2) enhance the transfer of proteins from the endosome in to the cytosol so they can be loaded on to MHC Class I (85). This advantage is apparent when assessing cross-presentation of dead cell-derived antigens and upon stimulation with TLR3. However, recent data showed that murine CDC2 are also able to cross-present and cross-prime antigen upon stimulation with R848, a TLR7/8 agonist (86). In human, cDC1 appears to be superior at cross-presenting cell-derived antigen, particularly upon polyI:C stimulation $(19-21,71)$ and when antigens are delivered to late endosomes and lysosomes (87). However, in common with mice, cDC2 are also able to cross-present soluble antigen and long-peptide particularly upon R848 stimulation $(88,89)$. The variable findings reported may also be due to type of antigens used in the cross-presentation assays and the validity of comparing murine in vivo models with human in vitro assays.

In mouse, $\mathrm{cDC} 1$ preferentially induce Th1 immune response through IL-12p70 production $(90,91)$, although Th2 induction has also been reported (92). In human, both $\mathrm{CDC} 1$ and $\mathrm{cDC} 2$ have been shown to induce Th1 and Th2 responses (93). cDC1s were also shown to promote enhanced Th2 differentiation in response to TSLP in an influenza infection humanized mouse model (94). As most human experiments are performed using blood DCs and in vitro, it has been logistically difficult to establish pathogen and tissue-specific effects relevant for driving Th priming in vivo.

\section{cDC2 \\ Phenotype}

cDC2s in mice are lin $^{-} \mathrm{MHCII}{ }^{\mathrm{hi}} \mathrm{CD} 11 \mathrm{c}^{+} \mathrm{CD} 11 \mathrm{~b}^{+}$. However, this fraction also includes monocyte-derived cells and macrophages (95). This is demonstrated by the variable depletion of cells from this fraction in Flt3 or Csf1r KO mice suggesting contamination by Flt3-independent cells (75). This is in contrast to the near complete absence of cDC1 in Flt3 KO mice (74).

Genetic tracing using Clec9A-reporter mouse to identify all CDP-derived cells demonstrated near-complete labeling of $\mathrm{cDC} 1 \mathrm{~s}$ but variable labeling of $\mathrm{CD}_{11} \mathrm{~b}^{+}$DCs in NLT (68). Although this is in keeping with the presence of monocyte-derived cells and macrophages within $\mathrm{CD}_{11} \mathrm{~b}^{+}$cells, it does not exclude the possibility of an alternative DC differentiation program that does not undergo a monocyte or CDP intermediate stage. Splenic CD $11 b^{+}$DCs are divided into an $\mathrm{ESAM}^{\mathrm{hi}}$ population that requires Notch2-, Flt3, and LT $\beta$-signaling for its development and a monocyte-like $\mathrm{ESAM}^{\mathrm{lo}} \mathrm{Clec} 12 \mathrm{~A}^{+} \mathrm{CX} 3 \mathrm{CR} 1^{+}$population that is Flt3-independent and expresses high levels of CD14, TNF $\alpha$, CCR2, and Lyz2 (96). In murine lung, it has been possible to divide the $\mathrm{MHCII}^{+} \mathrm{CD} 11 \mathrm{c}^{+} \mathrm{CD} 11 \mathrm{~b}^{+}$fraction into $\mathrm{CD} 11 \mathrm{~b}^{+} \mathrm{CD} 64^{+}$ monocyte-macrophage cells and $\mathrm{CD} 11 \mathrm{~b}^{+} \mathrm{CD} 24^{+} \mathrm{cDC} 2 \mathrm{~s}(24)$. In murine skin, the $\mathrm{MHCII}^{+} \mathrm{CD} 11 \mathrm{~b}^{+}$Langerin $^{-}$fraction comprises cDC2, monocyte-derived cells, and macrophages (97).

There is evidence that similar heterogeneity may be present within human cDC2. Only 170 genes characterized human cDC2, in comparison to 1020 for $\mathrm{CDC1}$ and 1065 genes for pDCs (23). This limited list of differentially expressed genes predicts heterogeneity within the boundaries of the phenotype parameters used to define human $\mathrm{CDC} 2$, specifically a subpopulation derived from or closely related to another mononuclear phagocyte such as $\mathrm{CD} 14^{+}$monocytes.

Human $\mathrm{cDC} 2\left(\mathrm{CD} 1 \mathrm{c}^{+} \mathrm{DCs}\right)$ are defined as lin $^{-} \mathrm{MHCII}^{+} \mathrm{CD} 14^{-}$ $\mathrm{CD}_{16}{ }^{-} \mathrm{CD} 11 \mathrm{c}^{+} \mathrm{CD} 1 \mathrm{c}^{+}$cells, a definition they share with in vitro monocyte-derived DCs. Although human peripheral blood and murine cDC2 additionally express CD11b, CX3CR1, and SIRP $\alpha$, these antigens do not distinguish them from monocyte-derived cells $(24,98)$. Uniquely in the small intestine, cDC2s co-express $\mathrm{CD} 103$ and $\operatorname{SIRP} \alpha(24,26)$. In vitro human mo-DCs express 
CD206/MMR and CD1a but peripheral blood cDC2 do not (47, 99). However, tissue CD1c ${ }^{+}$DCs express CD206 and CD1a (100, 101). In addition, some tissue $\mathrm{CD}^{+} \mathrm{c}^{+} \mathrm{DCs}$ co-express CD14 particularly during inflammation (47).

\section{Homology}

The transcriptional signatures of human blood $\mathrm{CD}_{1} \mathrm{c}^{+} \mathrm{DCs}$ are enriched with that of mouse spleen $\mathrm{CD}^{+} / \mathrm{CD} 11 \mathrm{~b}^{+} \mathrm{DCs}(17,23)$. In NLT, the transcriptional signatures of human small intestine $\mathrm{CD}_{103}{ }^{+} \mathrm{SIRP}^{+} \mathrm{DCs}$ and dermal CD1c $\mathrm{c}^{+} \mathrm{DCs}$ are enriched with that of murine spleen and mesenteric lymph node CD11 $b^{+}$DCs and dermal CD $11 b^{+}$DCs, respectively $(25,26)$. A similar relationship was also observed between murine lung CD11b+ DCs with human blood CD1c ${ }^{+}$DCs (24).

\section{Transcription Factors}

cDC2 development has been shown to be dependent on the TFs Irf4, PU.1, RelB, and RBPJ (24, 96, 102-108). Irf4 directly supports MHC class II antigen presentation to promote $\mathrm{CD}^{+}$ $\mathrm{T}$ cell responses (109). In humans, $\mathrm{CD}^{+} \mathrm{c}^{+} \mathrm{DCs}$ express high amounts of IRF4 (24). Interestingly, IRF4 is also required for mo-DC differentiation, suggesting a shared differentiation program between cDC2 and mo-DC. PU.1 interacts with Irf4 but also upregulates Flt3 expression critical for early DC differentiation in mice $(110,111)$. The PU.1 binding site in the Flt3 promoter is conserved in mice and humans, and so it is thought to be similarly required for DC differentiation in humans (111). Administration of Flt3 results in expansion of DC subsets in lymphoid and non-lymphoid tissue (112). PU.1 mutations in humans and mice are associated with myeloid leukemias (113). Biallelic human IRF8 K108E mutation resulted in complete loss of monocytes, $\mathrm{pDCs}, \mathrm{cDC} 1$, and $\mathrm{cDC} 2$ in the peripheral blood (60). Surprisingly, human autosomal dominant IRF8 T108A mutation results in selective loss of the cDC2 subset and IL-12 production (60). It is now apparent from studies on Irf8 ${ }^{\mathrm{R} 294 \mathrm{C}}(\mathrm{BXH} 2)$ and $\mathrm{Irf8}^{-/-}$mice that in addition to $\mathrm{CDC} 1, \mathrm{pDCs}$ and monocytes are also dependent on IRF8 (73, 75, 114-116). However, cDC2 frequency in mice with $\mathrm{Irf8}^{-/-}$and the hypomorphic mutation $\mathrm{Irf}^{\mathrm{R} 294 \mathrm{C}}$ are unaffected, in contrast to the findings in humans $(73,75,114)$.

\section{Function}

The transcriptome of $\mathrm{CDC} 2 \mathrm{~s}$ is enriched for genes related to antigen processing such as LAMP1, LAMP2, and cathepsins (117). Murine cDC2s have been shown to be able to promote Th17, Th2, and regulatory $\mathrm{T}$ cell responses depending upon the pathogen and antigen stimulus $(24,108,118-120)$. This may be a consequence of their innate plasticity but could also relate to unresolved heterogeneity within murine $\mathrm{CDC} 2$. In human, $\mathrm{CDC} 2$ have been shown to induce Th17 differentiation (24).

Both human and mouse cDC2 share many transcriptional and functional similarities with monocyte-derived cells $(24,25$, $47,97)$. Both cDC2 and mo-DC are capable of promoting naïve $\mathrm{CD}^{+}$and $\mathrm{CD}^{+} \mathrm{T}$ cell proliferation and in mice $\mathrm{CDC} 2$ appear to be superior at trafficking to lymph nodes $(97,98)$, leading to the hypothesis that mo-DCs specialize in activating tissue-tropic $\mathrm{T}$ cells. Mo-DCs also produce higher levels of monocyte-attracting chemokines (CCL2, CCL7, CCL12) than cDC2s (98). Human blood $\mathrm{CDC} 2$ have a TLR expression profile that is close to murine lymphoid cDC2 with significantly higher levels of TLRs 2, 4, and 5 than other DC subsets (81), a profile it also shares with in vitro mo-DCs (121). The pathogenic role of cDC2 in human disease is not clear but they have been shown to accumulate in conditions such as RA (122), chronic kidney disease (123), and atopic airway inflammation (124), although their distinction from inflammatory mo-DCs is unclear. Human cDC2 are also implicated in the accumulation of $\mathrm{CD} 103^{+} \mathrm{CD}^{+}$mucosal $\mathrm{T}$ cells in the lung and promote fibrosis in the kidney through production of TGF $\beta$ (123, 125). Finally, human and mouse $\mathrm{CDC} 2$ share a similar cytokine production profile which includes IL-6, IL-23, and IL-1 $\beta(24,81$, $126,127)$. In addition, unlike murine $\mathrm{cDC} 2$, human blood cDC2 can secrete high amounts of IL-12p70 upon in vitro stimulation with R848 and LPS, which was augmented in the presence of IFN $\gamma$ and CD40L (89).

\section{Plasmacytoid DCs (pDCs) Phenotype}

Plasmacytoid DCs are specialized IFN $\alpha$ producing cells that were first described in human peripheral blood and tonsil (128-131). In blood, their morphology resembles that of lymphocytes but upon in vitro culture with IL-3 and CD40L, they acquire dendrites resembling myeloid DCs (129). pDCs are identified in mice by expression of CD $11 c^{\text {int }} \mathrm{CD} 11 \mathrm{~b}^{-} \mathrm{B} 220^{+}$in combination with markers such as SiglecH and CD317 (BST2) to exclude a subset of NK cells and precursors of cDCs (132). In humans, they are identified by expression of CD123, CD303, and CD304. CD123 is the IL-3 receptor alpha chain and is also expressed on precursor cells, basophils, and eosinophils $(133,134)$. CD303 (BDCA-2) is a C-type lectin that is specifically expressed by human pDCs (135). Functionally, it has a role in antigen capture and when ligated it inhibits IFN $\alpha$ production (136). CD304 (BDCA-4) is uniquely expressed by pDC in peripheral blood but is also expressed by other cells such as endothelial cells (137).

\section{Homology}

The relative distance of the $\mathrm{pDC}$ transcriptome from other leukocyte subsets and its conservation directly aligns murine and human pDCs (17). However, a subset of murine pDCs also appears to have $\mathrm{CDC}$ differentiation potential $(138,139)$, which has not been observed in human.

\section{Transcription Factors}

Plasmacytoid DC development in humans and mice is dependent on the transcription factor E2-2 (140). E2-2 opposes default differentiation of precursors into $\mathrm{cDCs}$ and controls expression of a range of $\mathrm{pDC}$-associated TFs, including SpiB, Irf7, and Irf8 $(140,141)$. In humans, haploinsufficiency of E2-2 results in Pitt-Hopkins syndrome, a condition with a range of features including developmental delay and characteristic facial features but without known clinical immunodeficiency (142). A population of CD45RA ${ }^{+} \mathrm{CD} 123^{+}$cells is present in the blood of patients with Pitt-Hopkins syndrome but these cells fail to express CD303 and have severely reduced expression of IFN $\alpha$, indicating that loss of E2-2 blocks full pDC differentiation (140). The transcription factor 
SpiB is required for IFN $\alpha$ production by $\mathrm{pDC}$ in mice (143). SpiBknockdown in human CD34 ${ }^{+}$HSCs inhibits pDC differentiation in vitro (144).

\section{Function}

Plasmacytoid DCs have a functional program that is wellconserved between mice and humans (145). In contrast to cDCs, pDCs express a narrow range of pattern recognition (146). Both mouse and human pDCs express TLR7 and TLR9 (146). TLR8 is expressed at very low amounts if any by human $\operatorname{pDCs}(81,147,148)$ and appears to have a different function in mice $(146,149,150)$. pDCs in both mice and humans are specialized in the production of IFN $\alpha$ and thought to be important in viral immunity but also human autoimmunity such as SLE $(151,152)$.

\section{Monocytes and Monocyte-Derived Cells Phenotype}

Two subsets of monocytes exist in mice and can be distinguished by the differential expression of Ly6C, CCR2, and CX3CR1. Similarly in humans, there are two monocyte subsets in peripheral blood identified by expression of CD14 and CD16 (CD14 ${ }^{++} \mathrm{CD} 16^{-}$ and $\mathrm{CD} 14^{+} \mathrm{CD} 16^{+}$) as well as an intermediate phenotype $\left(\mathrm{CD} 14^{++} \mathrm{CD} 16^{+}\right)$. In addition to these antigens, human monocytes are also heterogeneous for the expression of the angiopoietin receptor, Tie2, and 6-sulfoLanNAc(Slan), a carbohydrate modification of the P-selectin glycoprotein ligand-1 (PSGL-1) $(153,154)$.

\section{Homology}

Homology between peripheral blood monocyte subsets has been demonstrated by the extensive transcript enrichment between Ly6C $^{\text {hi } C X 3 C R} 1^{\text {lo }}$ and $\mathrm{CD} 14^{++} \mathrm{CD} 16^{-}$monocytes and between ${\text { Ly } 6 C^{\text {lo }} \text { CX } 3 C R 1}^{\text {hi }}$ and CD16 ${ }^{+}$monocytes $(18,23,155)$.

\section{Transcription Factors}

The TFs that regulate the sequential differentiation of HSCs into MDP in mice include PU.1, Irf8, and Klf4 [reviewed in Ref. (156)]. PU.1 is required at each developmental bifurcation including HSC maintenance (157) and the generation of early myeloid progenitors $(16,158-160)$. Similarly in humans, PU.1 is required for monocyte differentiation from $\mathrm{CD} 34^{+}$cord blood precursors (161). In murine monopoiesis, Irf8 and Klf4 act together to skew differentiation toward monocytes by antagonizing the granulocyte-supporting TF $\mathrm{C} / \mathrm{EBP} \alpha(115,162)$. Consistent with this, human autosomal recessive Irf8 deficiency results in complete loss of circulating monocytes and DCs in the presence of neutrophilia (60).

The TFs that control cell-fate decisions downstream of MDP are less well defined. In mice, Irf5 and TCFEB are implicated during MDP to CMoP differentiation (55). The TF Nur77 has been implicated in $\mathrm{Ly}_{6} \mathrm{C}^{\mathrm{lo}} \mathrm{CX} 3 \mathrm{CR} 1^{\text {hi }}$ monocyte generation (163).

PU.1 and MafB act antagonistically to support human monocyte differentiation into mo-DC and mo-Mac, respectively in vitro (164). Irf4 was also implicated in human in vitro mo-DC differentiation (165). Irf5 promotes the differentiation of classical/M1 macrophages from human monocytes in vitro (166). In contrast, Irf4 activates transcription of the alternative/M2 macrophage markers in mice (167) and humans $(168,169)$.

\section{Function}

$\mathrm{CD}_{1} 4^{+}$human and $\mathrm{Ly} 6 \mathrm{C}^{\text {hi }} \mathrm{CX} 3 \mathrm{CR} 1^{\text {lo }}$ murine monocytes can exhibit considerable functional plasticity as demonstrated by their acquisition of DC-like and macrophage-like characteristics in vitro and in vivo. Recent fate mapping studies have demonstrated that monocytes do not contribute to tissue-resident macrophages in the steady state $(12,14,15)$, with the notable exception of gut and dermal macrophages $(14,97,170)$. However, monocytes can give rise to tissue macrophage-like cells in inflammation $(35,171)$. Monocytes can also differentiate into DC-like cells in the steady state in mucosal tissues and skin $(97,172)$. This process is enhanced during inflammation $(97,98,173)$, including infections with Leishmania (34), Influenza (174), Trypanosoma (175), Listeria (33), and pulmonary Aspergillus (176). Alternatively, rather than DC-like or macrophage-like differentiation, monocytes may remain as tissue monocytes upon extravasation (177).

$\mathrm{CD} 14^{+} \mathrm{CD} 16^{+}$intermediate and $\mathrm{CD} 16^{+}$non-classical monocytes are expanded in multiple disease, infection, and inflammatory states (178). CD16 $6^{+}$monocytes "patrol" the endothelium in vivo, are weak phagocytes, and sense nucleic acids and viruses via TLR7 and 8 receptors (155). Additional heterogeneity has been reported within human monocytes. Tie $2^{+}$monocytes are associated with angiogenesis and $\mathrm{Slan}^{+} \mathrm{CD} 16^{+}$cells, which are also present in inflamed skin, are potent producers of TNF $\alpha$, IL- $1 \beta$, and IL-12 $(179,180)$. Monocyte-derived dermal CD $14^{+}$cells express IL- $1 \alpha$ (25) have been shown to induce differentiation of follicular helper T cells (126) and provide direct B cell help (181).

\section{Langerhans Cells}

Langerhans cells are located in epidermal surfaces such as skin and are characterized by the presence of cytoplasmic organelles containing Langerin called Birbeck granules (182). The function of these organelles is unclear but their absence does not affect their capacity to process and present antigen (183). LCs form a dynamic network with adjacent keratinocytes and protrude dendrites through tight junctions to pick up antigens that have passed the stratum corneum barrier (184). The easy accessibility of LCs and their functional plasticity has generated significant interest in targeting them for vaccination strategies (185).

In the steady state, LCs are maintained independently of the bone marrow through local self-renewal (186-188). Human LCs can proliferate in situ and have been shown to remain donor in origin up to 10 years after limb transplant (189-191). During inflammation, LCs can be replaced by circulating precursors. The identity of the circulating LC precursor remains unclear. In mice, there appears to be two waves of replenishment with monocytes in the first wave giving rise to short-term LCs that retain some monocyte features and an as yet unknown $\mathrm{CD} 34^{+}$ HSC-derived precursor that gives rise to long-term LCs (186, 187). In humans, CD1c $c^{+}$DCs are able to upregulate langerin and CD1a, a phenotype resembling LCs, upon in vitro culture with TSLP and TGF $\beta$ or GM-CSF and BMP7, but the relevance of this to in vivo LC differentiation is uncertain $(192,193)$. Although human LCs can self-renew locally after BMT, they are replaced by donor-derived cells, even after non-myeloablative transplant conditioning (194-196). 
Langerhans cells are developmentally independent of Flt3 but dependent on Csf1r. However, it is IL-34 signaling through Csf1r, rather than Csf1, that is critical for LC development and maintenance (197). IL-34 is also expressed in human skin but the dependence of human LCs on this cytokine remains untested.

\section{Phenotype}

Human and murine LCs are CD11c $c^{\text {lo }}$, langerin ${ }^{\text {hi }}, \mathrm{EPCAM}^{+}$, and also characterized by the presence of cytoplasmic Birbeck granules (198). In human, LCs are additionally CD $1 \mathrm{a}^{\text {hi }}$ and $\mathrm{CD} 1 \mathrm{c}^{+}(23,199)$.

\section{Homology}

The homology between LCs in humans and mouse is obvious given their exclusive anatomical occupancy and shared expression of langerin, EPCAM, and presence of Birbeck granules. Comparative transcriptomic analysis of human and mouse LCs has never been performed.

\section{Transcription Factors}

Langerhans cell development is dependent on PU.1, Runx3, and Id2, although the latter may be dispensable for bone marrowderived LCs $(74,188,200,201)$.

\section{Function}

Langerhans cells are able to induce different immune responses depending on the context. Depletion of murine LCs can either exacerbate or suppress contact hypersensitivity immune response [reviewed in Ref. (202)]. In a mouse model of graft versus host disease (GVHD), LCs neither primed CD8 ${ }^{+} \mathrm{T}$ cells nor programed their homing to the epidermis but were required for their effector function in situ (203). This is consistent with their inability to cross-present antigen in vivo $(80,204)$, although cross-presentation has been reported using in vitro assays (205). In mice, LCs appear to be critical for Th17 response against the yeast form of Candida albicans in the epidermis through engagement of Dectin- 1 and their subsequent production of IL-6 (206). In humans, failure to generate effective Th17 responses (as a result of a range of mutations in, for example, IL-17RA, IL-17F, STAT1 genes) can result in chronic mucocutaneous candidiasis (CMC) (207). However, it is unclear if immunity against Candida infections in the skin in healthy individuals is dependent upon LCs. Notably, human LCs do not appear to express Dectin-1, which is important for Candida recognition (208). In vitro human LCs appear versatile and are capable of generating Th1, Th2 (209), Th17 (210), Th22 (211), and Treg (212) responses depending on the experimental conditions used.

\section{Macrophages}

Macrophages are a diverse population of tissue-resident cells with roles in inflammation, tissue homeostasis, and repair. Macrophage identity and function can be influenced by three variables: (1) resident tissue environment; (2) exposure to activation signals; and (3) ontogeny (monocyte- vs. prenatal precursor-derived) [reviewed in Ref. (3)].

The nomenclature of macrophages is based upon their tissue of origin [for example, Kupffer cells (liver), osteoclasts (bone), and microglia (CNS)]. This is in recognition of the central influence of environment on their phenotype and function. Examples of these functional specializations include breakdown of RBCs (Kupffer cells and splenic macrophages), bone resorption (osteoclasts), gut peristalsis (muscularis macrophages), and neural network development and maintenance (microglia) (213-215). Although macrophages in the vast majority of tissues, except dermis and the lamina propria, are prenatally derived, their preservation into adulthood by self-renewal is variable by site and in the presence of inflammation $[(15,216,217)$ and reviewed in Ref. (218)]. The relative preservation of dermal macrophages and LCs in patients lacking circulating blood monocytes and DCs due to heterozygote GATA2 and biallelic IRF8 deficiencies supports a prenatal origin of some human macrophages $(59,60)$.

Microarray transcriptome analysis has identified several thousand transcripts with greater than twofold difference in expression between macrophages from different sites in mice (219), supporting unique local microenvironment-related characteristics. These tissue specific transcripts are more prominent within macrophages than DCs (219) and may reflect the tissue-resident nature of macrophages. The impact and underlying mechanisms of environmental regulation on macrophages was elegantly demonstrated by the unique epigenetic modulation of macrophage in distinct tissues and the ability of macrophages from one environment to develop the characteristics of their counterparts in another tissue $(220,221)$.

\section{Phenotype}

Murine macrophages express the antigens CD11b, CD68, CSF1R, and $\mathrm{F} 4 / 80$ (215). With the exception of $\mathrm{F} 4 / 80$ which is predominantly expressed on eosinophils (222), these antigens are also expressed on human macrophages (223). Furthermore, human alveolar macrophages were shown to express many antigens, which are conserved at transcript level with murine bone marrow-derived macrophages (163).

\section{Homology}

Comparative analysis between human and mouse macrophage populations has been poorly studied. In skin, homologous monocyte-derived dermal macrophage populations have been identified (25) but the murine counterparts of human dermal macrophages containing melanin-granules (melanophages) remain uncertain. While a range of transcriptional analyses of human macrophage populations in health and disease have been performed, comparisons between human tissues and across species have not been rigorously undertaken (224).

\section{Transcription Factors}

The transcriptional requirements of murine YS-derived macrophages differ to those of HSC-derived macrophages. YS-derived microglia require PU.1 and Irf8 but are independent of Myb, Id2, Batf3, and Klf4 $(2,12,225)$. Consistent with macrophage tissue specializations, additional TFs such NFATc1 and Spi-C have been shown to be required for osteoclasts and splenic and bone marrow macrophage differentiation, respectively (226-228).

\section{Function}

The M1/M2 paradigm has been described to model the diverse programs of macrophage activation but has largely relied on 
in vitro generated macrophages. This has provided a useful tool to examine macrophage activation in the absence of tissue-specific effects. More recently, a spectrum of responses, with M1 and M2 being two poles of a continuum that is transcriptionally apparent, were identified (229). It is unclear how closely human and murine macrophages are aligned in response to a similar range of stimuli. There are inter-species differences in the response to a single stimulus (LPS) between human and mouse in vitro derived macrophages; INOS transcript is preferentially induced in mouse but human macrophages characteristically upregulate CCL20, CXCL13, IL-7R, P2RX7, and STAT4 (230).

\section{Mononuclear Phagocytes in Inflammation}

Classical Ly6 $\mathrm{C}^{\text {hi }} \mathrm{CX} 3 \mathrm{CR} 1^{\text {lo }}$ monocytes infiltrate inflamed tissues where they can acquire either DC or macrophage properties (33, 231). This in vivo process (thought to be analogous to in vitro mo-Mac and mo-DC differentiation) can be influenced by local microbiota $(97,98,170,171)$. In infection and disease, monocytederived cells accumulate in greater numbers in a broad range of tissues [reviewed in Ref. (232)]. In many such models of infection, they are non-redundant and required for clearance of pathogens by promoting protective Th1 and Th17 responses (34, 233, 234). This suggests that despite shared functions with resident conventional DCs, there are important differences that require the presence of monocyte-derived cells to overcome infection. In murine experimental autoimmune encephalomyelitis, monocytes infiltrate the CNS but are not long-lived and following resolution do not contribute to the microglial pool (231). Analysis of murine Kupffer cells suggests functional heterogeneity between resident and recruited populations (235).

Snapshot analysis of inflamed human tissue similarly reveals additional subsets that are not present in health $[(47,99,179$, 236, 237) and reviewed in Ref. (31)]. These include inflammatory dendritic epidermal cells (IDECs) found in atopic dermatitis, TNF, and iNOS producing DCs (Tip DCs) and slan DCs, found in psoriasis $(99,179,236,237)$. In rheumatoid arthritis synovial

\section{References}

1. Merad M, Sathe P, Helft J, Miller J, Mortha A. The dendritic cell lineage: ontogeny and function of dendritic cells and their subsets in the steady state and the inflamed setting. Annu Rev Immunol (2013) 31:563-604. doi:10.1146/ annurev-immunol-020711-074950

2. Ginhoux F, Jung S. Monocytes and macrophages: developmental pathways and tissue homeostasis. Nat Rev Immunol (2014) 14:392-404. doi:10.1038/nri3671

3. Varol C, Mildner A, Jung S. Macrophages: development and tissue specialization. Annu Rev Immunol (2015) 33:643-75. doi:10.1146/ annurev-immunol-032414-112220

4. Banchereau J, Steinman RM. Dendritic cells and the control of immunity. Nature (1998) 392:245-52. doi:10.1038/32588

5. Steinman RM, Banchereau J. Taking dendritic cells into medicine. Nature (2007) 449:419-26. doi:10.1038/nature06175

6. van Furth R, Cohn ZA, Hirsch JG, Humphrey JH, Spector WG, Langevoort $\mathrm{HL}$. The mononuclear phagocyte system: a new classification of macrophages, monocytes, and their precursor cells. Bull World Health Organ (1972) 46:845-52.

7. van Furth R. Current view on the mononuclear phagocyte system. Immunobiology (1982) 161:178-85. doi:10.1016/S0171-2985(82)80072-7

8. Cline MJ. Bactericidal activity of human macrophages: analysis of factors influencing the killing of Listeria monocytogenes. Infect Immun (1970) 2:156-61. fluid and malignant ascites, there is an accumulation of cells that express overlapping markers with blood CD1c $\mathrm{c}^{+} \mathrm{DCs}$ but additionally express CD1a, CD206, SIRP $\alpha$, and CD14 (47). Monocytes can acquire DC characteristics when cultured with ex vivo GM-CSF-primed synovial T cells, which potentially suggests a mechanism for their generation (238). Histiocytes are pathological MPs expressing CD68 and CD163. It is unknown if these cells, often found in granulomas, arise from resident macrophages or are monocyte-derived. Further studies are required to establish the in vivo differentiation requirements of inflammatory MP populations and how they contribute to disease.

\section{Conclusion}

In this review, we have discussed the parallel organization of the MPS between humans and mice. We demonstrate the use of comparative biology approaches as both a validation and discovery tool to dissect the development and functional heterogeneity of mononuclear phagocytes in a reciprocal manner across the two species. The incorporation of high-dimensional unbiased single-cell genomics and proteomics technologies will facilitate the interrogation of functionally relevant populations with indiscrete phenotypes and validate current definitions of cell-types based on limited antigen expression profile particularly during inflammation. This combined strategy will accelerate the translation of fundamental MPS biology to clinical benefit through enhanced understanding of the pathomechanisms of disease and facilitate the development of novel approaches in vaccination and cancer immunotherapy.

\section{Acknowledgments}

MH and GR are funded by The Wellcome Trust, UK [Intermediate Clinical Fellowship; WT088555A (MH) and Clinical Research Training Fellowship; WT098914MA (GR)]. The authors wish to acknowledge Matthew Collin for assistance with illustration.

9. Sallusto F, Lanzavecchia A. Efficient presentation of soluble antigen by cultured human dendritic cells is maintained by granulocyte/macrophage colony-stimulating factor plus interleukin 4 and downregulated by tumor necrosis factor alpha. J Exp Med (1994) 179:1109-18. doi:10.1084/jem.179.4.1109

10. Caux C, Vanbervliet B, Massacrier C, Dezutter-Dambuyant C, de Saint-Vis B, Jacquet C, et al. CD34+ hematopoietic progenitors from human cord blood differentiate along two independent dendritic cell pathways in response to GM-CSF+TNF alpha. J Exp Med (1996) 184:695-706. doi:10.1084/ jem.184.2.695

11. Liu K, Victora GD, Schwickert TA, Guermonprez P, Meredith MM, Yao K, et al. In vivo analysis of dendritic cell development and homeostasis. Science (2009) 324:392-7. doi:10.1126/science.1170540

12. Schulz C, Gomez Perdiguero E, Chorro L, Szabo-Rogers H, Cagnard N, Kierdorf $\mathrm{K}$, et al. A lineage of myeloid cells independent of Myb and hematopoietic stem cells. Science (2012) 336:86-90. doi:10.1126/science.1219179

13. Hoeffel G, Wang Y, Greter M, See P, Teo P, Malleret B, et al. Adult Langerhans cells derive predominantly from embryonic fetal liver monocytes with a minor contribution of yolk sac-derived macrophages. J Exp Med (2012) 209:1167-81. doi:10.1084/jem.20120340

14. Yona S, Kim KW, Wolf Y, Mildner A, Varol D, Breker M, et al. Fate mapping reveals origins and dynamics of monocytes and tissue macrophages under homeostasis. Immunity (2013) 38:79-91. doi:10.1016/j.immuni.2012.12.001 
15. Perdiguero EG, Klapproth K, Schulz C, Busch K, Azzoni E, Crozet L, et al. Tissue-resident macrophages originate from yolk-sac-derived erythro-myeloid progenitors. Nature (2014) 518(7540):547-51. doi:10.1038/nature13989

16. Hoeffel G, Chen J, Lavin Y, Low D, Almeida FF, See P, et al. C-myb(+) erythro-myeloid progenitor-derived fetal monocytes give rise to adult tissue-resident macrophages. Immunity (2015) 42:665-78. doi:10.1016/j.immuni.2015.03.011

17. Robbins SH, Walzer T, Dembele D, Thibault C, Defays A, Bessou G, et al. Novel insights into the relationships between dendritic cell subsets in human and mouse revealed by genome-wide expression profiling. Genome Biol (2008) 9:R17. doi:10.1186/gb-2008-9-1-r17

18. Ingersoll MA, Spanbroek R, Lottaz C, Gautier EL, Frankenberger M, Hoffmann $\mathrm{R}$, et al. Comparison of gene expression profiles between human and mouse monocyte subsets. Blood (2010) 115:e10-9. doi:10.1182/blood-2009-07-235028

19. Bachem A, Guttler S, Hartung E, Ebstein F, Schaefer M, Tannert A, et al. Superior antigen cross-presentation and XCR1 expression define human CD11c+CD141+ cells as homologues of mouse CD8+ dendritic cells. J Exp Med (2010) 207:1273-81. doi:10.1084/jem.20100348

20. Crozat K, Guiton R, Contreras V, Feuillet V, Dutertre CA, Ventre E, et al. The $\mathrm{XC}$ chemokine receptor 1 is a conserved selective marker of mammalian cells homologous to mouse CD8alpha+ dendritic cells. JExp Med (2010) 207:1283-92. doi:10.1084/jem.20100223

21. Jongbloed SL, Kassianos AJ, McDonald KJ, Clark GJ, Ju X, Angel CE, et al. Human CD141+ (BDCA-3)+ dendritic cells (DCs) represent a unique myeloid DC subset that cross-presents necrotic cell antigens. J Exp Med (2010) 207:1247-60. doi:10.1084/jem.20092140

22. Poulin LF, Reyal Y, Uronen-Hansson H, Schraml BU, Sancho D, Murphy KM, et al. DNGR-1 is a specific and universal marker of mouse and human Batf3dependent dendritic cells in lymphoid and nonlymphoid tissues. Blood (2012) 119:6052-62. doi:10.1182/blood-2012-01-406967

23. Haniffa M, Shin A, Bigley V, McGovern N, Teo P, See P, et al. Human tissues contain CD141(hi) cross-presenting dendritic cells with functional homology to mouse CD103(+) nonlymphoid dendritic cells. Immunity (2012) 37:60-73. doi:10.1016/j.immuni.2012.04.012

24. Schlitzer A, McGovern N, Teo P, Zelante T, Atarashi K, Low D, et al. IRF4 transcription factor-dependent CD11b+ dendritic cells in human and mouse control mucosal IL-17 cytokine responses. Immunity (2013) 38:970-83. doi:10.1016/j. immuni.2013.04.011

25. McGovern N, Schlitzer A, Gunawan M, Jardine L, Shin A, Poyner E, et al. Human dermal CD14(+) cells are a transient population of monocyte-derived macrophages. Immunity (2014) 41:465-77. doi:10.1016/j.immuni.2014.08.006

26. Watchmaker PB, Lahl K, Lee M, Baumjohann D, Morton J, Kim SJ, et al. Comparative transcriptional and functional profiling defines conserved programs of intestinal DC differentiation in humans and mice. Nat Immunol (2014) 15:98-108. doi:10.1038/ni.2768

27. Lee J, Breton G, Oliveira TY, Zhou YJ, Aljoufi A, Puhr S, et al. Restricted dendritic cell and monocyte progenitors in human cord blood and bone marrow. J Exp Med (2015) 212:385-99. doi:10.1084/jem.20141442

28. Breton G, Lee J, Zhou YJ, Schreiber JJ, Keler T, Puhr S, et al. Circulating precursors of human CD1c+ and CD141+ dendritic cells. J Exp Med (2015) 212:401-13. doi:10.1084/jem.20141441

29. Waterston RH, Lindblad-Toh K, Birney E, Rogers J, Abril JF, Agarwal P, et al. Initial sequencing and comparative analysis of the mouse genome. Nature (2002) 420:520-62. doi:10.1038/nature01262

30. Haniffa M, Collin M, Ginhoux F. Ontogeny and functional specialization of dendritic cells in human and mouse. Adv Immunol (2013) 120:1-49. doi:10.1016/ B978-0-12-417028-5.00001-6

31. Haniffa M, Gunawan M, Jardine L. Human skin dendritic cells in health and disease. J Dermatol Sci (2015) 77(2):85-92. doi:10.1016/j.jdermsci.2014.08.012

32. Collin M, Bigley V, Haniffa M, Hambleton S. Human dendritic cell deficiency: the missing ID? Nat Rev Immunol (2011) 11:575-83. doi:10.1038/nri3046

33. Serbina NV, Salazar-Mather TP, Biron CA, Kuziel WA, Pamer EG. TNF/ iNOS-producing dendritic cells mediate innate immune defense against bacterial infection. Immunity (2003) 19:59-70. doi:10.1016/S1074-7613(03)00171-7

34. Leon B, Lopez-Bravo M, Ardavin C. Monocyte-derived dendritic cells formed at the infection site control the induction of protective Thelper 1 responses against Leishmania. Immunity (2007) 26:519-31. doi:10.1016/j.immuni.2007.01.017

35. Serbina NV, Hohl TM, Cherny M, Pamer EG. Selective expansion of the monocytic lineage directed by bacterial infection. J Immunol (2009) 183:1900-10. doi:10.4049/jimmunol.0900612
36. de Jong E, Suddason T, Lord GM. Translational mini-review series on Th17 cells: development of mouse and human T helper 17 cells. Clin Exp Immunol (2010) 159:148-58. doi:10.1111/j.1365-2249.2009.04041.x

37. Noster R, Riedel R, Mashreghi MF, Radbruch H, Harms L, Haftmann C, et al. IL-17 and GM-CSF expression are antagonistically regulated by human Thelper cells. Sci Transl Med (2014) 6:241 ra80. doi:10.1126/scitranslmed.3008706

38. Codarri L, Gyulveszi G, Tosevski V, Hesske L, Fontana A, Magnenat L, et al. RORgammat drives production of the cytokine GM-CSF in helper T cells, which is essential for the effector phase of autoimmune neuroinflammation. Nat Immunol (2011) 12:560-7. doi:10.1038/ni.2027

39. Roncarolo MG, Battaglia M. Regulatory T-cell immunotherapy for tolerance to self antigens and alloantigens in humans. Nat Rev Immunol (2007) 7:585-98. doi:10.1038/nri2138

40. Mestas J, Hughes CC. Of mice and not men: differences between mouse and human immunology. J Immunol (2004) 172:2731-8. doi:10.4049/ jimmunol.172.5.2731

41. Van Rhijn I, Ly D, Moody DB. CD1a, CD1b, and CD1c in immunity against mycobacteria. AdvExpMed Biol(2013) 783:181-97.doi:10.1007/978-1-4614-6111-1_10

42. van de Mortel JE, Aarts MG. Comparative transcriptomics - model species lead the way. New Phytol (2006) 170:199-201.doi:10.1111/j.1469-8137.2006.01708.x

43. Shay T, Jojic V, Zuk O, Rothamel K, Puyraimond-Zemmour D, Feng T, et al. Conservation and divergence in the transcriptional programs of the human and mouse immune systems. Proc Natl Acad Sci U S A (2013) 110:2946-51. doi:10.1073/pnas.1222738110

44. Subramanian A, Tamayo P, Mootha VK, Mukherjee S, Ebert BL, Gillette MA, et al. Gene set enrichment analysis: a knowledge-based approach for interpreting genome-wide expression profiles. Proc Natl Acad Sci US A (2005) 102:15545-50. doi:10.1073/pnas.0506580102

45. Lamb J, Crawford ED, Peck D, Modell JW I, Blat C, Wrobel MJ, et al. The connectivity map: using gene-expression signatures to connect small molecules, genes, and disease. Science (2006) 313:1929-35. doi:10.1126/science.1132939

46. Lindstedt M, Lundberg K, Borrebaeck CA. Gene family clustering identifies functionally associated subsets of human in vivo blood and tonsillar dendritic cells. J Immunol (2005) 175:4839-46. doi:10.4049/jimmunol.175.8.4839

47. Segura E, Touzot M, Bohineust A, Cappuccio A, Chiocchia G, Hosmalin A, et al. Human inflammatory dendritic cells induce th17 cell differentiation. Immunity (2013) 38:336-48. doi:10.1016/j.immuni.2012.10.018

48. Jaitin DA, Kenigsberg E, Keren-Shaul H, Elefant N, Paul F, Zaretsky I, et al. Massively parallel single-cell RNA-seq for marker-free decomposition of tissues into cell types. Science (2014) 343:776-9. doi:10.1126/science.1247651

49. Mahata B, Zhang X, Kolodziejczyk AA, Proserpio V, Haim-Vilmovsky L, Taylor AE, et al. Single-cell RNA sequencing reveals Thelper cells synthesizing steroids de novo to contribute to immune homeostasis. Cell Rep (2014) 7:1130-42. doi:10.1016/j.celrep.2014.04.011

50. Trapnell C, Cacchiarelli D, Grimsby J, Pokharel P, Li S, Morse M, et al. The dynamics and regulators of cell fate decisions are revealed by pseudotemporal ordering of single cells. Nat Biotechnol (2014) 32:381-6. doi:10.1038/nbt.2859

51. Treutlein B, Brownfield DG, Wu AR, Neff NF, Mantalas GL, Espinoza FH, et al. Reconstructing lineage hierarchies of the distal lung epithelium using single-cell RNA-seq. Nature (2014) 509:371-5. doi:10.1038/nature13173

52. Durruthy-Durruthy R, Gottlieb A, Hartman BH, Waldhaus J, Laske RD, Altman $\mathrm{R}$, et al. Reconstruction of the mouse otocyst and early neuroblast lineage at single-cell resolution. Cell (2014) 157:964-78. doi:10.1016/j.cell.2014.03.036

53. Arsenio J, Kakaradov B, Metz PJ, Kim SH, Yeo GW, Chang JT. Early specification of CD8+ T lymphocyte fates during adaptive immunity revealed by single-cell gene-expression analyses. Nat Immunol (2014) 15:365-72. doi:10.1038/ni.2842

54. Luber CA, Cox J, Lauterbach H, Fancke B, Selbach M, Tschopp J, et al. Quantitative proteomics reveals subset-specific viral recognition in dendritic cells. Immunity (2010) 32:279-89. doi:10.1016/j.immuni.2010.01.013

55. Hettinger J, Richards DM, Hansson J, Barra MM, Joschko AC, Krijgsveld J, et al. Origin of monocytes and macrophages in a committed progenitor. Nat Immunol (2013) 14:821-30. doi:10.1038/ni.2638

56. Amir, el- AD, Davis KL, Tadmor MD, Simonds EF, Levine JH, Bendall SC, et al. viSNE enables visualization of high dimensional single-cell data and reveals phenotypic heterogeneity of leukemia. Nat Biotechnol (2013) 31:545-52. doi:10.1038/nbt.2594

57. Becher B, Schlitzer A, Chen J, Mair F, Sumatoh HR, Teng KW, et al. Highdimensional analysis of the murine myeloid cell system. Nat Immunol (2014) 15(12):1181-9. doi:10.1038/ni.3006 
58. Segura E, Amigorena S. Cross-presentation by human dendritic cell subsets. Immunol Lett (2014) 158:73-8. doi:10.1016/j.imlet.2013.12.001

59. Bigley V, Haniffa M, Doulatov S, Wang XN, Dickinson R, McGovern N, et al. The human syndrome of dendritic cell, monocyte, B and NK lymphoid deficiency. J Exp Med (2011) 208:227-34. doi:10.1084/jem.20101459

60. Hambleton S, Salem S, Bustamante J, Bigley V, Boisson-Dupuis S, Azevedo J, et al. IRF8 mutations and human dendritic-cell immunodeficiency. $N$ Engl J Med (2011) 365(2):127-38. doi:10.1056/NEJMoal100066

61. Guilliams M, Ginhoux F, Jakubzick C, Naik SH, Onai N, Schraml BU, et al. Dendritic cells, monocytes and macrophages: a unified nomenclature based on ontogeny. Nat Rev Immunol (2014) 14(8):571-8. doi:10.1038/nri3712

62. Naik SH, Sathe P, Park HY, Metcalf D, Proietto AI, Dakic A, et al. Development of plasmacytoid and conventional dendritic cell subtypes from single precursor cells derived in vitro and in vivo. Nat Immunol (2007) 8:1217-26. doi:10.1038/ ni1522

63. Onai N, Kurabayashi K, Hosoi-Amaike M, Toyama-Sorimachi N, Matsushima $\mathrm{K}$, Inaba K, et al. A clonogenic progenitor with prominent plasmacytoid dendritic cell developmental potential. Immunity (2013) 38:943-57. doi:10.1016/j. immuni.2013.04.006

64. Galibert L, Diemer GS, Liu Z, Johnson RS, Smith JL, Walzer T, et al. Nectinlike protein 2 defines a subset of T-cell zone dendritic cells and is a ligand for class-I-restricted T-cell-associated molecule. J Biol Chem (2005) 280:21955-64. doi:10.1074/jbc.M502095200

65. Bachem A, Hartung E, Guttler S, Mora A, Zhou X, Hegemann A, et al. Expression of XCR1 characterizes the Batf3-dependent lineage of dendritic cells capable of antigen cross-presentation. Front Immunol (2012) 3:214. doi:10.3389/ fimmu.2012.00214

66. Contreras V, Urien C, Guiton R, Alexandre Y, Vu Manh TP, Andrieu T, et al. Existence of CD8alpha-like dendritic cells with a conserved functional specialization and a common molecular signature in distant mammalian species. J Immunol (2010) 185:3313-25. doi:10.4049/jimmunol.1000824

67. Tatsumi K, Taatjes DJ, Wadsworth MP, Bouchard BA, Bovill EG. Cell adhesion molecule 1 (CADM1) is ubiquitously present in the endothelium and smooth muscle cells of the human macro- and micro-vasculature. Histochem Cell Biol (2012) 138:815-20. doi:10.1007/s00418-012-1024-2

68. Schraml BU, van Blijswijk J, Zelenay S, Whitney PG, Filby A, Acton SE, et al. Genetic tracing via DNGR-1 expression history defines dendritic cells as a hematopoietic lineage. Cell (2013) 154:843-58. doi:10.1016/j.cell.2013.07.014

69. Ginhoux F, Collin MP, Bogunovic M, Abel M, Leboeuf M, Helft J, et al. Bloodderived dermal langerin+ dendritic cells survey the skin in the steady state. J Exp Med (2007) 204:3133-46. doi:10.1084/jem.20071733

70. Bigley V, McGovern N, Milne P, Dickinson R, Pagan S, Cookson S, et al. Langerinexpressing dendritic cells in human tissues are related to $\mathrm{CD} 1 \mathrm{c}+$ dendritic cells and distinct from Langerhans cells and CD141high XCR1+ dendritic cells. J Leukoc Biol (2014) 97(4):627-34. doi:10.1189/jlb.1HI0714-351R

71. Poulin LF, Salio M, Griessinger E, Anjos-Afonso F, Craciun L, Chen JL, et al. Characterization of human DNGR-1+ BDCA3+ leukocytes as putative equivalents of mouse CD8alpha+ dendritic cells. J Exp Med (2010) 207:1261-71. doi:10.1084/jem.20092618

72. Hildner K, Edelson BT, Purtha WE, Diamond M, Matsushita H, Kohyama M, et al. Batf3 deficiency reveals a critical role for CD8alpha+ dendritic cells in cytotoxic T cell immunity. Science (2008) 322:1097-100. doi:10.1126/science.1164206

73. Schiavoni G, Mattei F, Sestili P, Borghi P, Venditti M, Morse HCR, et al. ICSBP is essential for the development of mouse type I interferon-producing cells and for the generation and activation of CD8alpha(+) dendritic cells. J Exp Med (2002) 196:1415-25. doi:10.1084/jem.20021263

74. Hacker C, Kirsch RD, Ju XS, Hieronymus T, Gust TC, Kuhl C, et al. Transcriptional profiling identifies Id2 function in dendritic cell development. Nat Immunol (2003) 4:380-6. doi:10.1038/ni903

75. Ginhoux F, Liu K, Helft J, Bogunovic M, Greter M, Hashimoto D, et al. The origin and development of nonlymphoid tissue CD103+ DCs. JExp Med (2009) 206:3115-30. doi:10.1084/jem.20091756

76. Kashiwada M, Pham NL, Pewe LL, Harty JT, Rothman PB. NFIL3/E4BP4 is a key transcription factor for CD8alpha(+) dendritic cell development. Blood (2011) 117:6193-7. doi:10.1182/blood-2010-07-295873

77. Tussiwand R, Lee WL, Murphy TL, Mashayekhi M, KC W, Albring JC, et al. Compensatory dendritic cell development mediated by BATF-IRF interactions. Nature (2012) 490:502-7. doi:10.1038/nature11531
78. den Haan JM, Lehar SM, Bevan MJ. CD8(+) but not CD8(-) dendritic cells cross-prime cytotoxic T cells in vivo. J Exp Med (2000) 192:1685-96. doi:10.1084/ jem.192.12.1685

79. Iyoda T, Shimoyama S, Liu K, Omatsu Y, Akiyama Y, Maeda Y, et al. The CD8+ dendritic cell subset selectively endocytoses dying cells in culture and in vivo. J Exp Med (2002) 195:1289-302. doi:10.1084/jem.20020161

80. Bedoui S, Whitney PG, Waithman J, Eidsmo L, Wakim L, Caminschi I, et al. Cross-presentation of viral and self antigens by skin-derived CD103+ dendritic cells. Nat Immunol (2009) 10:488-95. doi:10.1038/ni.1724

81. Hemont C, Neel A, Heslan M, Braudeau C, Josien R. Human blood mDC subsets exhibit distinct TLR repertoire and responsiveness. J Leukoc Biol (2013) 93:599-609. doi:10.1189/jlb.0912452

82. Schulz O, Edwards AD, Schito M, Aliberti J, Manickasingham S, Sher A, et al. $\mathrm{CD} 40$ triggering of heterodimeric IL-12 $\mathrm{p} 70$ production by dendritic cells in vivo requires a microbial priming signal. Immunity (2000) 13:453-62. doi:10.1016/ S1074-7613(00)00045-5

83. Lauterbach H, Bathke B, Gilles S, Traidl-Hoffmann C, Luber CA, Fejer G, et al. Mouse CD8alpha+ DCs and human BDCA3+ DCs are major producers of IFN-lambda in response to poly IC. J Exp Med (2010) 207:2703-17. doi:10.1084/ jem.20092720

84. Savina A, Peres A, Cebrian I, Carmo N, Moita C, Hacohen N, et al. The small GTPase Rac2 controls phagosomal alkalinization and antigen crosspresentation selectively in CD8(+) dendritic cells. Immunity (2009) 30:544-55. doi:10.1016/j. immuni.2009.01.013

85. Lin ML, Zhan Y, Proietto AI, Prato S, Wu L, Heath WR, et al. Selective suicide of cross-presenting CD8+ dendritic cells by cytochrome c injection shows functional heterogeneity within this subset. Proc Natl Acad Sci U S A (2008) 105:3029-34. doi:10.1073/pnas.0712394105

86. Desch AN, Gibbings SL, Clambey ET, Janssen WJ, Slansky JE, Kedl RM, et al. Dendritic cell subsets require cis-activation for cytotoxic CD8 T-cell induction. Nat Commun (2014) 5:4674. doi:10.1038/ncomms5674

87. Cohn L, Chatterjee B, Esselborn F, Smed-Sorensen A, Nakamura N, Chalouni $\mathrm{C}$, et al. Antigen delivery to early endosomes eliminates the superiority of human blood BDCA3+ dendritic cells at cross presentation. J Exp Med (2013) 210:1049-63. doi:10.1084/jem.20121251

88. Segura E, Durand M, Amigorena S. Similar antigen cross-presentation capacity and phagocytic functions in all freshly isolated human lymphoid organ-resident dendritic cells. J Exp Med (2013) 210:1035-47. doi:10.1084/jem.20121103

89. Nizzoli G, Krietsch J, Weick A, Steinfelder S, Facciotti F, Gruarin P, et al. Human $\mathrm{CD} 1 \mathrm{c}+$ dendritic cells secrete high levels of IL-12 and potently prime cytotoxic T-cell responses. Blood (2013) 122:932-42. doi:10.1182/blood-2013-04-495424

90. Mashayekhi M, Sandau MM I, Dunay R, Frickel EM, Khan A, Goldszmid RS, et al. CD8alpha $(+)$ dendritic cells are the critical source of interleukin-12 that controls acute infection by Toxoplasma gondii tachyzoites. Immunity (2011) 35:249-59. doi:10.1016/j.immuni.2011.08.008

91. Martinez-Lopez M, Iborra S, Conde-Garrosa R, Sancho D. Batf3-dependent CD103+ dendritic cells are major producers of IL-12 that drive local Th1 immunity against Leishmania major infection in mice. Eur J Immunol (2015) 45:119-29. doi:10.1002/eji.201444651

92. Nakano H, Free ME, Whitehead GS, Maruoka S, Wilson RH, Nakano K, et al. Pulmonary CD103(+) dendritic cells prime Th2 responses to inhaled allergens. Mucosal Immunol (2012) 5:53-65. doi:10.1038/mi.2011.47

93. Segura E, Valladeau-Guilemond J, Donnadieu M-H, Sastre-Garau X, Soumelis $\mathrm{V}$, Amigorena S. Characterization of resident and migratory dendritic cells in human lymph nodes. J Exp Med (2012) 209:653-60. doi:10.1084/jem.20111457

94. Yu CI, Becker C, Metang P, Marches F, Wang Y, Toshiyuki H, et al. Human $\mathrm{CD} 141+$ dendritic cells induce CD4+ T cells to produce type 2 cytokines. J Immunol (2014) 193(9):4335-43. doi:10.4049/jimmunol.1401159

95. Ginhoux F, Schlitzer A. CD11b+DCs rediscovered: implications for vaccination. Expert Rev Vaccines (2014) 13:445-7. doi:10.1586/14760584.2014.893196

96. Lewis KL, Caton ML, Bogunovic M, Greter M, Grajkowska LT, Ng D, et al. Notch2 receptor signaling controls functional differentiation of dendritic cells in the spleen and intestine. Immunity (2011) 35:780-91. doi:10.1016/j. immuni.2011.08.013

97. Tamoutounour S, Guilliams M, Montanana Sanchis F, Liu H, Terhorst D, Malosse C, et al. Origins and functional specialization of macrophages and of conventional and monocyte-derived dendritic cells in mouse skin. Immunity (2013) 39:925-38. doi:10.1016/j.immuni.2013.10.004 
98. Plantinga M, Guilliams M, Vanheerswynghels M, Deswarte K, Branco-Madeira F, Toussaint W, et al. Conventional and monocyte-derived CD11b(+) dendritic cells initiate and maintain Thelper 2 cell-mediated immunity to house dust mite allergen. Immunity (2013) 38:322-35. doi:10.1016/j.immuni.2012.10.016

99. Wollenberg A, Mommaas M, Oppel T, Schottdorf EM, Gunther S, Moderer M. Expression and function of the mannose receptor CD206 on epidermal dendritic cells in inflammatory skin diseases. J Invest Dermatol (2002) 118:327-34. doi:10.1046/j.0022-202x.2001.01665.x

100. Zaba LC, Fuentes-Duculan J, Steinman RM, Krueger JG, Lowes MA. Normal human dermis contains distinct populations of CD11c+BDCA-1+ dendritic cells and CD163+FXIIIA+ macrophages. J Clin Invest (2007) 117:2517-25. doi:10.1172/JCI32282

101. Ochoa MT, Loncaric A, Krutzik SR, Becker TC, Modlin RL. Dermal dendritic cells" comprise two distinct populations: CD1(+) dendritic cells and CD209(+) macrophages. J Invest Dermatol (2008) 128(9):2225-31. doi:10.1038/jid.2008.56

102. Wu L, D’Amico A, Winkel KD, Suter M, Lo D, Shortman K. RelB is essential for the development of myeloid-related CD8alpha- dendritic cells but not of lymphoid-related CD8alpha+ dendritic cells. Immunity (1998) 9:839-47. doi:10.1016/S1074-7613(00)80649-4

103. Guerriero A, Langmuir PB, Spain LM, Scott EW. PU.1 is required for myeloid-derived but not lymphoid-derived dendritic cells. Blood (2000) 95:879-85.

104. Suzuki S, Honma K, Matsuyama T, Suzuki K, Toriyama K, Akitoyo I, et al. Critical roles of interferon regulatory factor 4 in CD1 lbhighCD8alpha- dendritic cell development. Proc Natl Acad Sci U S A (2004) 101:8981-6. doi:10.1073/ pnas.0402139101

105. Tamura T, Tailor P, Yamaoka K, Kong HJ, Tsujimura H, O’Shea JJ, et al. IFN regulatory factor- 4 and -8 govern dendritic cell subset development and their functional diversity. J Immunol (2005) 174:2573-81. doi:10.4049/jimmunol.174.5.2573

106. Caton ML, Smith-Raska MR, Reizis B. Notch-RBP-J signaling controls the homeostasis of CD8- dendritic cells in the spleen. JExp Med (2007) 204:1653-64.

107. Satpathy AT, Briseno CG, Lee JS, NgD, ManieriNA, KcW, et al. Notch2-dependent classical dendritic cells orchestrate intestinal immunity to attaching-and-effacing bacterial pathogens. Nat Immunol (2013) 14:937-48. doi:10.1038/ni.2679

108. Williams JW, Tjota MY, Clay BS, Vander Lugt B, Bandukwala HS, Hrusch CL, et al. Transcription factor IRF4 drives dendritic cells to promote Th2 differentiation. Nat Commun (2013) 4:2990. doi:10.1038/ncomms3990

109. Vander Lugt B, Khan AA, Hackney JA, Agrawal S, Lesch J, Zhou M, et al. Transcriptional programming of dendritic cells for enhanced MHC class II antigen presentation. Nat Immunol (2014) 15:161-7. doi:10.1038/ni.2795

110. Brass AL, Kehrli E, Eisenbeis CF, Storb U, Singh H. Pip, a lymphoid-restricted IRF, contains a regulatory domain that is important for autoinhibition and ternary complex formation with the Ets factor PU.1. Genes Dev (1996) 10:2335-47. doi:10.1101/gad.10.18.2335

111. Carotta S, Dakic A, D’Amico A, Pang SH, Greig KT, Nutt SL, et al. The transcription factor PU.1 controls dendritic cell development and Flt3 cytokine receptor expression in a dose-dependent manner. Immunity (2010) 32:628-41. doi:10.1016/j.immuni.2010.05.005

112. Maraskovsky E, Daro E, Roux E, Teepe M, Maliszewski CR, Hoek J, et al. In vivo generation of human dendritic cell subsets by Flt3 ligand. Blood (2000) 96:878-84.

113. Dakic A, Wu L, Nutt SL. Is PU.1 a dosage-sensitive regulator of haemopoietic lineage commitment and leukaemogenesis? Trends Immunol (2007) 28:108-14. doi:10.1016/j.it.2007.01.006

114. Tailor P, Tamura T, Morse HCR, Ozato K. The BXH2 mutation in IRF8 differentially impairs dendritic cell subset development in the mouse. Blood (2008) 111:1942-5. doi:10.1182/blood-2007-07-100750

115. Kurotaki D, Osato N, Nishiyama A, Yamamoto M, Ban T, Sato H, et al. Essential role of the IRF8-KLF4 transcription factor cascade in murine monocyte differentiation. Blood (2013) 121:1839-49. doi:10.1182/blood-2012-06-437863

116. Yanez A, Ng MY, Hassanzadeh-Kiabi N, Goodridge HS. IRF8 acts in lineage-committed rather than oligopotent progenitors to control neutrophil vs monocyte production. Blood (2015) 125:1452-9. doi:10.1182/blood-2014-09-600833

117. Dudziak D, Kamphorst AO, Heidkamp GF, Buchholz VR, Trumpfheller C, Yamazaki S, et al. Differential antigen processing by dendritic cell subsets in vivo. Science (2007) 315:107-11. doi:10.1126/science.1136080

118. Persson EK, Uronen-Hansson H, Semmrich M, Rivollier A, Hagerbrand K, Marsal J, et al. IRF4 transcription-factor-dependent CD103(+)CD11b(+) dendritic cells drive mucosal T helper 17 cell differentiation. Immunity (2013) 38:958-69. doi:10.1016/j.immuni.2013.03.009
119. Gao Y, Nish SA, Jiang R, Hou L, Licona-Limon P, Weinstein JS, et al. Control of T helper 2 responses by transcription factor IRF4-dependent dendritic cells. Immunity (2013) 39:722-32. doi:10.1016/j.immuni.2013.08.028

120. Zhou Q, Ho AW, Schlitzer A, Tang Y, Wong KH, Wong FH, et al. GM-CSFlicensed CD11b+ lung dendritic cells orchestrate Th2 immunity to blomia tropicalis. J Immunol (2014) 193:496-509. doi:10.4049/jimmunol.1303138

121. Iwasaki A, Medzhitov R. Toll-like receptor control of the adaptive immune responses. Nat Immunol (2004) 5:987-95. doi:10.1038/ni1112

122. Moret FM, Hack CE, van der Wurff-Jacobs KM, de Jager W, Radstake TR, Lafeber FP, et al. Intra-articular CD1c-expressing myeloid dendritic cells from rheumatoid arthritis patients express a unique set of T cell-attracting chemokines and spontaneously induce Th1, Th17 and Th2 cell activity. Arthritis Res Ther (2013) 15:R155. doi:10.1186/ar4338

123. Kassianos AJ, Wang X, Sampangi S, Muczynski K, Healy H, Wilkinson R. Increased tubulointerstitial recruitment of human CD141(hi) CLEC9A(+) and $\mathrm{CD} 1 \mathrm{c}(+)$ myeloid dendritic cell subsets in renal fibrosis and chronic kidney disease. Am J Physiol Renal Physiol (2013) 305:F1391-401. doi:10.1152/ ajprenal.00318.2013

124. Jahnsen FL, Moloney ED, Hogan T, Upham JW, Burke CM, Holt PG. Rapid dendritic cell recruitment to the bronchial mucosa of patients with atopic asthma in response to local allergen challenge. Thorax (2001) 56:823-6. doi:10.1136/ thorax.56.11.823

125. Yu CI, Becker C, Wang Y, Marches F, Helft J, Leboeuf M, et al. Human CD1c dendritic cells drive the differentiation of CD103 CD8 mucosal effector T cells via the cytokine TGF-beta. Immunity (2013) 38(4):818-30. doi:10.1016/j. immuni.2013.03.004

126. Klechevsky E, Morita R, Liu M, Cao Y, Coquery S, Thompson-Snipes L, et al. Functional specializations of human epidermal Langerhans cells and CD14+ dermal dendritic cells. Immunity (2008) 29:497-510. doi:10.1016/j. immuni.2008.07.013

127. Haniffa M, Ginhoux F, Wang XN, Bigley V, Abel M, Dimmick I, et al. Differential rates of replacement of human dermal dendritic cells and macrophages during hematopoietic stem cell transplantation. J Exp Med (2009) 206:371-85. doi:10.1084/jem.20081633

128. O’Doherty U, Peng M, Gezelter S, Swiggard WJ, Betjes M, Bhardwaj N, et al. Human blood contains two subsets of dendritic cells, one immunologically mature and the other immature. Immunology (1994) 82:487-93.

129. Grouard G, Rissoan MC, Filgueira L, Durand I, Banchereau J, Liu YJ. The enigmatic plasmacytoid T cells develop into dendritic cells with interleukin (IL)-3 and CD40-ligand. J Exp Med (1997) 185:1101-11. doi:10.1084/ jem.185.6.1101

130. Cella M, Jarrossay D, Facchetti F, Alebardi O, Nakajima H, Lanzavecchia A, et al. Plasmacytoid monocytes migrate to inflamed lymph nodes and produce large amounts of type I interferon. Nat Med (1999) 5:919-23. doi:10.1038/11360

131. Siegal FP, Kadowaki N, Shodell M, Fitzgerald-Bocarsly PA, Shah K, Ho S, et al. The nature of the principal type 1 interferon-producing cells in human blood. Science (1999) 284:1835-7. doi:10.1126/science.284.5421.1835

132. Satpathy AT, Wu X, Albring JC, Murphy KM. Re(de)fining the dendritic cell lineage. Nat Immunol (2012) 13:1145-54. doi:10.1038/ni.2467

133. Taussig DC, Pearce DJ, Simpson C, Rohatiner AZ, Lister TA, Kelly G, et al. Hematopoietic stem cells express multiple myeloid markers: implications for the origin and targeted therapy of acute myeloid leukemia. Blood (2005) 106:4086-92. doi:10.1182/blood-2005-03-1072

134. Toba K, Koike T, Shibata A, Hashimoto S, Takahashi M, Masuko M, et al. Novel technique for the direct flow cytofluorometric analysis of human basophils in unseparated blood and bone marrow, and the characterization of phenotype and peroxidase of human basophils. Cytometry (1999) 35:249-59. doi:10.1002/ (SICI)1097-0320(19990301)35:3<249::AID-CYTO8>3.3.CO;2-F

135. Dzionek A, Fuchs A, Schmidt P, Cremer S, Zysk M, Miltenyi S, et al. BDCA-2, BDCA-3, and BDCA-4: three markers for distinct subsets of dendritic cells in human peripheral blood. J Immunol (2000) 165:6037-46. doi:10.4049/ jimmunol.165.11.6037

136. Dzionek A, Sohma Y, Nagafune J, Cella M, Colonna M, Facchetti F, et al. BDCA-2, a novel plasmacytoid dendritic cell-specific type II C-type lectin, mediates antigen capture and is a potent inhibitor of interferon alpha/beta induction. J Exp Med (2001) 194:1823-34. doi:10.1084/jem.194.12.1823

137. Lebre MC, Jongbloed SL, Tas SW, Smeets TJ I, McInnes B, Tak PP. Rheumatoid arthritis synovium contains two subsets of CD83-DC-LAMP- dendritic cells 
with distinct cytokine profiles. Am J Pathol (2008) 172:940-50. doi:10.2353/ ajpath.2008.070703

138. Schlitzer A, Loschko J, Mair K, Vogelmann R, Henkel L, Einwachter H, et al. Identification of CCR9- murine plasmacytoid DC precursors with plasticity to differentiate into conventional DCs. Blood (2011) 117:6562-70. doi:10.1182/ blood-2010-12-326678

139. Schlitzer A, Heiseke AF, Einwachter H, Reindl W, Schiemann M, Manta CP, et al. Tissue-specific differentiation of a circulating CCR9- pDC-like common dendritic cell precursor. Blood (2012) 119:6063-71. doi:10.1182/blood-2012-03-418400

140. Cisse B, Caton ML, Lehner M, Maeda T, Scheu S, Locksley R, et al. Transcription factor E2-2 is an essential and specific regulator of plasmacytoid dendritic cell development. Cell (2008) 135:37-48. doi:10.1016/j.cell.2008.09.016

141. Ghosh HS, Cisse B, Bunin A, Lewis KL, Reizis B. Continuous expression of the transcription factor e2-2 maintains the cell fate of mature plasmacytoid dendritic cells. Immunity (2010) 33:905-16. doi:10.1016/j.immuni.2010.11.023

142. Peippo M, Ignatius J. Pitt-Hopkins syndrome. Mol Syndromol (2012) 2:171-80.

143. Sasaki I, Hoshino K, Sugiyama T, Yamazaki C, Yano T, Iizuka A, et al. Spi-B is critical for plasmacytoid dendritic cell function and development. Blood (2012) 120:4733-43. doi:10.1182/blood-2012-06-436527

144. Schotte R, Nagasawa M, Weijer K, Spits H, Blom B. The ETS transcription factor Spi-B is required for human plasmacytoid dendritic cell development. J Exp Med (2004) 200:1503-9. doi:10.1084/jem.20041231

145. Hochrein H, O'Keeffe M, Wagner H. Human and mouse plasmacytoid dendritic cells. Hum Immunol (2002) 63:1103-10. doi:10.1016/S0198-8859(02)00748-6

146. Fuchsberger M, Hochrein H, O'Keeffe M. Activation of plasmacytoid dendritic cells. Immunol Cell Biol (2005) 83:571-7. doi:10.1111/j.1440-1711.2005.01392.x

147. Jarrossay D, Napolitani G, Colonna M, Sallusto F, Lanzavecchia A. Specialization and complementarity in microbial molecule recognition by human myeloid and plasmacytoid dendritic cells. Eur J Immunol (2001) 31:3388-93. doi:10.1002/1521-4141(200111)31:11<3388::AID-IMMU3388>3.0.CO;2-Q

148. Kadowaki N, Ho S, Antonenko S, Malefyt RW, Kastelein RA, Bazan F, et al. Subsets of human dendritic cell precursors express different toll-like receptors and respond to different microbial antigens. JExp Med (2001) 194:863-9. doi:10.1084/ jem.194.6.863

149. Demaria O, Pagni PP, Traub S, de Gassart A, Branzk N, Murphy AJ, et al. TLR8 deficiency leads to autoimmunity in mice. J Clin Invest (2010) 120:3651-62. doi:10.1172/JCI42081

150. Desnues B, Macedo AB, Roussel-Queval A, Bonnardel J, Henri S, Demaria O, et al. TLR8 on dendritic cells and TLR9 on B cells restrain TLR7-mediated spontaneous autoimmunity in C57BL/6 mice. Proc Natl Acad Sci U S A (2014) 111:1497-502. doi:10.1073/pnas.1314121111

151. Gilliet M, Cao W, Liu YJ. Plasmacytoid dendritic cells: sensing nucleic acids in viral infection and autoimmune diseases. Nat Rev Immunol (2008) 8:594-606. doi:10.1038/nri2358

152. Garcia-Romo GS, Caielli S, Vega B, Connolly J, Allantaz F, Xu Z, et al. Netting neutrophils are major inducers of type I IFN production in pediatric systemic lupus erythematosus. Sci Transl Med (2011) 3:73ra20. doi:10.1126/ scitranslmed.3001201

153. Murdoch C, Tazzyman S, Webster S, Lewis CE. Expression of tie-2 by human monocytes and their responses to angiopoietin-2. JImmunol (2007) 178:7405-11. doi:10.4049/jimmunol.178.11.7405

154. Schakel K, Kannagi R, Kniep B, Goto Y, Mitsuoka C, Zwirner J, et al. 6-Sulfo LacNAc, a novel carbohydrate modification of PSGL-1, defines an inflammatory type of human dendritic cells. Immunity (2002) 17:289-301. doi:10.1016/ S1074-7613(02)00393-X

155. Cros J, Cagnard N, Woollard K, Patey N, Zhang SY, Senechal B, et al. Human CD14dim monocytes patrol and sense nucleic acids and viruses via TLR7 and TLR8 receptors. Immunity (2010) 33:375-86. doi:10.1016/j.immuni.2010.08.012

156. Rosenbauer F, Tenen DG. Transcription factors in myeloid development: balancing differentiation with transformation. Nat Rev Immunol (2007) 7:105-17. doi:10.1038/nri2024

157. Staber PB, Zhang P, Ye M, Welner RS, Nombela-Arrieta C, Bach C, et al. Sustained PU.1 levels balance cell-cycle regulators to prevent exhaustion of adult hematopoietic stem cells. Mol Cell (2013) 49:934-46. doi:10.1016/j.molcel.2013.01.007

158. Scott EW, Simon MC, Anastasi J, Singh H. Requirement of transcription factor PU.1 in the development of multiple hematopoietic lineages. Science (1994) 265:1573-7. doi:10.1126/science.8079170
159. Kueh HY, Champhekar A, Nutt SL, Elowitz MB, Rothenberg EV. Positive feedback between PU.1 and the cell cycle controls myeloid differentiation. Science (2013) 341:670-3. doi:10.1126/science.1240831

160. Laslo P, Spooner CJ, Warmflash A, Lancki DW, Lee HJ, Sciammas R, et al. Multilineage transcriptional priming and determination of alternate hematopoietic cell fates. Cell (2006) 126:755-66. doi:10.1016/j.cell.2006.06.052

161. Rosa A, Ballarino M, Sorrentino A, Sthandier O, De Angelis FG, Marchioni M, et al. The interplay between the master transcription factor PU.1 and miR-424 regulates human monocyte/macrophage differentiation. Proc Natl Acad Sci US A (2007) 104:19849-54. doi:10.1073/pnas.0706963104

162. Kurotaki D, Yamamoto M, Nishiyama A, Uno K, Ban T, Ichino M, et al. IRF8 inhibits C/EBPalpha activity to restrain mononuclear phagocyte progenitors from differentiating into neutrophils. Nat Commun (2014) 5:4978. doi:10.1038/ ncomms5978

163. Hanna RN, Carlin LM, Hubbeling HG, Nackiewicz D, Green AM, Punt JA, et al. The transcription factor NR4A1 (Nur77) controls bone marrow differentiation and the survival of Ly6C- monocytes. Nat Immunol (2011) 12:778-85. doi:10.1038/ni.2063

164. Bakri Y, Sarrazin S, Mayer UP, Tillmanns S, Nerlov C, Boned A, et al. Balance of MafB and PU.1 specifies alternative macrophage or dendritic cell fate. Blood (2005) 105:2707-16. doi:10.1182/blood-2004-04-1448

165. Lehtonen A, Veckman V, Nikula T, Lahesmaa R, Kinnunen L, Matikainen S, et al. Differential expression of IFN regulatory factor 4 gene in human monocyte-derived dendritic cells and macrophages. J Immunol (2005) 175:6570-9. doi:10.4049/jimmunol.175.10.6570

166. Krausgruber T, Blazek K, Smallie T, Alzabin S, Lockstone H, Sahgal N, et al. IRF5 promotes inflammatory macrophage polarization and TH1-TH17 responses. Nat Immunol (2011) 12:231-8. doi:10.1038/ni.1990

167. Satoh T, Takeuchi O, Vandenbon A, Yasuda K, Tanaka Y, Kumagai Y, et al. The Jmjd3-Irf4 axis regulates M2 macrophage polarization and host responses against helminth infection. Nat Immunol (2010) 11:936-44. doi:10.1038/ni.1920

168. Derlindati E, Dei Cas A, Montanini B, Spigoni V, Curella V, Aldigeri R, et al. Transcriptomic analysis of human polarized macrophages: more than one role of alternative activation? PLoS One (2015) 10:e0119751. doi:10.1371/journal. pone. 0119751

169. Martinez FO, Helming L, Milde R, Varin A, Melgert BN, Draijer C, et al. Genetic programs expressed in resting and IL-4 alternatively activated mouse and human macrophages: similarities and differences. Blood (2013) 121:e57-69. doi:10.1182/ blood-2012-06-436212

170. Bain CC, Bravo-Blas A, Scott CL, Gomez Perdiguero E, Geissmann F, Henri $\mathrm{S}$, et al. Constant replenishment from circulating monocytes maintains the macrophage pool in the intestine of adult mice. Nat Immunol (2014) 15:929-37. doi:10.1038/ni.2967

171. Bain CC, Scott CL, Uronen-Hansson H, Gudjonsson S, Jansson O, Grip O, et al. Resident and pro-inflammatory macrophages in the colon represent alternative context-dependent fates of the same Ly6Chi monocyte precursors. Mucosal Immunol (2013) 6:498-510. doi:10.1038/mi.2012.89

172. Varol C, Landsman L, Fogg DK, Greenshtein L, Gildor B, Margalit R, et al. Monocytes give rise to mucosal, but not splenic, conventional dendritic cells. $J$ Exp Med (2007) 204:171-80. doi:10.1084/jem.20061011

173. Cheong C, Matos I, Choi JH, Dandamudi DB, Shrestha E, Longhi MP, et al. Microbial stimulation fully differentiates monocytes to DC-SIGN/CD209(+) dendritic cells for immune T cell areas. Cell (2010) 143:416-29. doi:10.1016/j. cell.2010.09.039

174. Nakano H, Lin KL, Yanagita M, Charbonneau C, Cook DN, Kakiuchi T, et al. Blood-derived inflammatory dendritic cells in lymph nodes stimulate acute $\mathrm{T}$ helper type 1 immune responses. Nat Immunol (2009) 10:394-402. doi:10.1038/ ni. 1707

175. Bosschaerts T, Guilliams M, Stijlemans B, Morias Y, Engel D, Tacke F, et al. Tip-DC development during parasitic infection is regulated by IL-10 and requires CCL2/CCR2, IFN-gamma and MyD88 signaling. PLoS Pathog (2010) 6:e1001045. doi:10.1371/journal.ppat.1001045

176. Hohl TM, Rivera A, Lipuma L, Gallegos A, Shi C, Mack M, et al. Inflammatory monocytes facilitate adaptive $\mathrm{CD} 4 \mathrm{~T}$ cell responses during respiratory fungal infection. Cell Host Microbe (2009) 6:470-81. doi:10.1016/j.chom.2009.10.007

177. Jakubzick C, Gautier EL, Gibbings SL, Sojka DK, Schlitzer A, Johnson TE, et al. Minimal differentiation of classical monocytes as they survey steady-state 
tissues and transport antigen to lymph nodes. Immunity (2013) 39:599-610. doi:10.1016/j.immuni.2013.08.007

178. Wong KL, Yeap WH, Tai JJ, Ong SM, Dang TM, Wong SC. The three human monocyte subsets: implications for health and disease. Immunol Res (2012) 53:41-57. doi:10.1007/s12026-012-8297-3

179. Hansel A, Gunther C, Ingwersen J, Starke J, Schmitz M, Bachmann M, et al. Human slan (6-sulfo LacNAc) dendritic cells are inflammatory dermal dendritic cells in psoriasis and drive strong TH17/TH1 T-cell responses. J Allergy Clin Immunol (2011) 127:.e1-9. doi:10.1016/j.jaci.2010.12.009

180. Brumeanu TD, Swiggard WJ, Steinman RM, Bona CA, Zaghouani H. Efficient loading of identical viral peptide onto class II molecules by antigenized immunoglobulin and influenza virus. J Exp Med (1993) 178:1795-9. doi:10.1084/ jem.178.5.1795

181. Matthews K, Chung NP, Klasse PJ, Moore JP, Sanders RW. Potent induction of antibody-secreting B cells by human dermal-derived CD14+ dendritic cells triggered by dual TLR ligation. J Immunol (2012) 189:5729-44. doi:10.4049/ jimmunol.1200601

182. Birbeck MS, Breathnach AS, Everall JD. An electron microscope study of basal melanocytes and high-level clear cells (Langerhans cells) in vitiligo. J Invest Dermatol (1961) 37:51-64. doi:10.1038/jid.1961.7

183. Kissenpfennig A, Ait-Yahia S, Clair-Moninot V, Stossel H, Badell E, Bordat $\mathrm{Y}$, et al. Disruption of the langerin/CD207 gene abolishes birbeck granules without a marked loss of Langerhans cell function. Mol Cell Biol (2005) 25:88-99. doi:10.1128/MCB.25.1.88-99.2005

184. Kubo A, Nagao K, Yokouchi M, Sasaki H, Amagai M. External antigen uptake by Langerhans cells with reorganization of epidermal tight junction barriers. $J$ Exp Med (2009) 206:2937-46. doi:10.1084/jem.20091527

185. Teunissen MB, Haniffa M, Collin MP. Insight into the immunobiology of human skin and functional specialization of skin dendritic cell subsets to innovate intradermal vaccination design. Curr Top Microbiol Immunol (2012) 351:25-76. doi:10.1007/82_2011_169

186. Sere K, Baek JH, Ober-Blobaum J, Muller-Newen G, Tacke F, Yokota Y, et al. Two distinct types of Langerhans cells populate the skin during steady state and inflammation. Immunity (2012) 37:905-16. doi:10.1016/j.immuni.2012.07.019

187. Nagao K, Kobayashi T, Moro K, Ohyama M, Adachi T, Kitashima DY, et al. Stress-induced production of chemokines by hair follicles regulates the trafficking of dendritic cells in skin. Nat Immunol (2012) 13:744-52. doi:10.1038/ ni. 2353

188. Chopin M, Seillet C, Chevrier S, Wu L, Wang H, Morse HCR, et al. Langerhans cells are generated by two distinct PU.1-dependent transcriptional networks. $J$ Exp Med (2013) 210:2967-80. doi:10.1084/jem.20130930

189. Chorro L, Sarde A, Li M, Woollard KJ, Chambon P, Malissen B, et al. Langerhans cell (LC) proliferation mediates neonatal development, homeostasis, and inflammation-associated expansion of the epidermal LC network. J Exp Med (2009) 206:3089-100. doi:10.1084/jem.20091586

190. Kanitakis J, Petruzzo P, Dubernard JM. Turnover of epidermal Langerhans' cells. N Engl J Med (2004) 351:2661-2. doi:10.1056/NEJM200412163512523

191. Kanitakis J, Morelon E, Petruzzo P, Badet L, Dubernard JM. Self-renewal capacity of human epidermal Langerhans cells: observations made on a composite tissue allograft. Exp Dermatol (2011) 20:145-6. doi:10.1111/j.1600-0625.2010.01146.x

192. Martinez-Cingolani C, Grandclaudon M, Jeanmougin M, Jouve M, Zollinger R, Soumelis V. Human blood BDCA-1 dendritic cells differentiate into Langerhanslike cells with thymic stromal lymphopoietin and TGF-beta. Blood (2014) 124:2411-20. doi:10.1182/blood-2014-04-568311

193. Milne P, Bigley V, Gunawan M, Haniffa M, Collin M. CD1c+ blood dendritic cells have Langerhans cell potential. Blood (2014) 125(3):470-3. doi:10.1182/ blood-2014-08-593582

194. Merad M, Manz MG, Karsunky H, Wagers A, Peters W, Charo I, et al. Langerhans cells renew in the skin throughout life under steady-state conditions. Nat Immunol (2002) 3:1135-41. doi:10.1038/ni852

195. Collin MP, Hart DN, Jackson GH, Cook G, Cavet J, Mackinnon S, et al. The fate of human Langerhans cells in hematopoietic stem cell transplantation. J Exp Med (2006) 203:27-33. doi:10.1084/jem.20051787

196. Mielcarek M, Kirkorian AY, Hackman RC, Price J, Storer BE, Wood BL, et al. Langerhans cell homeostasis and turnover after nonmyeloablative and myeloablative allogeneic hematopoietic cell transplantation. Transplantation (2014) 98(5):563-8. doi:10.1097/TP.0000000000000097
197. Greter M, Lelios I, Pelczar P, Hoeffel G, Price J, Leboeuf M, et al. Stroma-derived interleukin-34 controls the development and maintenance of Langerhans cells and the maintenance of microglia. Immunity (2012) 37:1050-60. doi:10.1016/j. immuni.2012.11.001

198. Kashihara M, Ueda M, Horiguchi Y, Furukawa F, Hanaoka M, Imamura S. A monoclonal antibody specifically reactive to human Langerhans cells. J Invest Dermatol (1986) 87:602-7. doi:10.1111/1523-1747.ep12455849

199. Stoitzner P, Romani N, McLellan AD, Tripp CH, Ebner S. Isolation of skin dendritic cells from mouse and man. Methods Mol Biol (2010) 595:235-48. doi:10.1007/978-1-60761-421-0_16

200. Fainaru O, Woolf E, Lotem J, Yarmus M, Brenner O, Goldenberg D, et al. Runx3 regulates mouse TGF-beta-mediated dendritic cell function and its absence results in airway inflammation. EMBO J (2004) 23:969-79. doi:10.1038/ sj.emboj.7600085

201. Chopin M, Nutt SL. Establishing and maintaining the Langerhans cell network. Semin Cell Dev Biol (2014). doi:10.1016/j.semcdb.2014.02.001

202. Kaplan DH, Kissenpfennig A, Clausen BE. Insights into Langerhans cell function from Langerhans cell ablation models. Eur J Immunol (2008) 38:2369-76. doi:10.1002/eji.200838397

203. Bennett CL, Fallah-Arani F, Conlan T, Trouillet C, Goold H, Chorro L, et al. Langerhans cells regulate cutaneous injury by licensing $\mathrm{CD} 8$ effector cells recruited to the skin. Blood (2011) 117(26):7063-9. doi:10.1182/blood-2011-01-329185

204. Henri S, Poulin LF, Tamoutounour S, Ardouin L, Guilliams M, de Bovis B, et al. CD207+ CD103+ dermal dendritic cells cross-present keratinocyte-derived antigens irrespective of the presence of Langerhans cells. J Exp Med (2010) 207:189-206. doi:10.1084/jem.20091964

205. Stoitzner P, Tripp CH, Eberhart A, Price KM, Jung JY, Bursch L, et al. Langerhans cells cross-present antigen derived from skin. Proc Natl Acad Sci U S A (2006) 103:7783-8. doi:10.1073/pnas.0509307103

206. Kashem SW, Igyarto BZ, Gerami-Nejad M, Kumamoto Y, Mohammed J, Jarrett E, et al. Candida albicans morphology and dendritic cell subsets determine $\mathrm{T}$ helper cell differentiation. Immunity (2015) 42:356-66. doi:10.1016/j. immuni.2015.01.008

207. Puel A, Cypowyj S, Marodi L, Abel L, Picard C, Casanova JL. Inborn errors of human IL-17 immunity underlie chronic mucocutaneous candidiasis. Curr Opin Allergy Clin Immunol (2012) 12:616-22. doi:10.1097/ACI.0b013e328358cc0b

208. Ni L, Gayet I, Zurawski S, Duluc D, Flamar AL, Li XH, et al. Concomitant activation and antigen uptake via human dectin-1 results in potent antigen-specific CD8+ T cell responses. J Immunol (2010) 185:3504-13. doi:10.4049/ jimmunol.1000999

209. Furio L, Briotet I, Journeaux A, Billard H, Peguet-Navarro J. Human Langerhans cells are more efficient than $\mathrm{CD} 14(-) \mathrm{CD} 1 \mathrm{c}(+)$ dermal dendritic cells at priming naive CD4(+) T cells. J Invest Dermatol (2010) 130:1345-54. doi:10.1038/ jid.2009.424

210. Mathers AR, Janelsins BM, Rubin JP, Tkacheva OA, Shufesky WJ, Watkins SC, et al. Differential capability of human cutaneous dendritic cell subsets to initiate Th17 responses. J Immunol (2009) 182:921-33. doi:10.4049/jimmunol.182.2.921

211. Fujita H, Nograles KE, Kikuchi T, Gonzalez J, Carucci JA, Krueger JG. Human Langerhans cells induce distinct IL-22-producing CD4+ T cells lacking IL-17 production. Proc Natl Acad Sci U S A (2009) 106:21795-800. doi:10.1073/ pnas.0911472106

212. Seneschal J, Clark RA, Gehad A, Baecher-Allan CM, Kupper TS. Human epidermal Langerhans cells maintain immune homeostasis in skin by activating skin resident regulatory t cells. Immunity (2012) 36(5):873-84. doi:10.1016/j. immuni.2012.03.018

213. Muller PA, Koscso B, Rajani GM, Stevanovic K, Berres ML, Hashimoto D, et al. Crosstalk between muscularis macrophages and enteric neurons regulates gastrointestinal motility. Cell (2014) 158:300-13. doi:10.1016/j.cell.2014.04.050

214. Paolicelli RC, Bolasco G, Pagani F, Maggi L, Scianni M, Panzanelli P, et al. Synaptic pruning by microglia is necessary for normal brain development. Science (2011) 333:1456-8. doi:10.1126/science. 1202529

215. Wynn TA, Chawla A, Pollard JW. Macrophage biology in development, homeostasis and disease. Nature (2013) 496:445-55. doi:10.1038/nature12034

216. Epelman S, Lavine KJ, Beaudin AE, Sojka DK, Carrero JA, Calderon B, et al. Embryonic and adult-derived resident cardiac macrophages are maintained through distinct mechanisms at steady state and during inflammation. Immunity (2014) 40:91-104. doi:10.1016/j.immuni.2013.11.019 
217. Guilliams M, De Kleer I, Henri S, Post S, Vanhoutte L, De Prijck S, et al. Alveolar macrophages develop from fetal monocytes that differentiate into long-lived cells in the first week of life via GM-CSF. J Exp Med (2013) 210:1977-92. doi:10.1084/ jem.20131199

218. Sieweke MH, Allen JE. Beyond stem cells: self-renewal of differentiated macrophages. Science (2013) 342:1242974. doi:10.1126/science.1242974

219. Gautier EL, Shay T, Miller J, Greter M, Jakubzick C, Ivanov S, et al. Geneexpression profiles and transcriptional regulatory pathways that underlie the identity and diversity of mouse tissue macrophages. Nat Immunol (2012) 13:1118-28. doi:10.1038/ni.2419

220. Lavin Y, Winter D, Blecher-Gonen R, David E, Keren-Shaul H, Merad M, et al. Tissue-resident macrophage enhancer landscapes are shaped by the local microenvironment. Cell (2014) 159:1312-26. doi:10.1016/j.cell.2014.11.018

221. Gosselin D, Link VM, Romanoski CE, Fonseca GJ, Eichenfield DZ, Spann NJ, et al. Environment drives selection and function of enhancers controlling tissue-specific macrophage identities. Cell (2014) 159:1327-40. doi:10.1016/j. cell.2014.11.023

222. Hamann J, Koning N, Pouwels W, Ulfman LH, van Eijk M, Stacey M, et al. EMR1, the human homolog of F4/80, is an eosinophil-specific receptor. Eur J Immunol (2007) 37:2797-802. doi:10.1002/eji.200737553

223. Murray PJ, Wynn TA. Protective and pathogenic functions of macrophage subsets. Nat Rev Immunol (2011) 11:723-37. doi:10.1038/nri3073

224. Gordon S, Pluddemann A, Martinez Estrada F. Macrophage heterogeneity in tissues: phenotypic diversity and functions. Immunol Rev (2014) 262:36-55. doi:10.1111/imr.12223

225. Kierdorf K, Erny D, Goldmann T, Sander V, Schulz C, Perdiguero EG, et al. Microglia emerge from erythromyeloid precursors via Pu.1- and Irf8-dependent pathways. Nat Neurosci (2013) 16:273-80. doi:10.1038/nn.3318

226. Takayanagi H, Kim S, Koga T, Nishina H, Isshiki M, Yoshida H, et al. Induction and activation of the transcription factor NFATc1 (NFAT2) integrate RANKL signaling in terminal differentiation of osteoclasts. Dev Cell (2002) 3:889-901. doi:10.1016/S1534-5807(02)00369-6

227. Kohyama M, Ise W, Edelson BT, Wilker PR, Hildner K, Mejia C, et al. Role for Spi-Cin the development of red pulp macrophages and splenic iron homeostasis. Nature (2009) 457:318-21. doi:10.1038/nature07472

228. Haldar M, Kohyama M, So AY, Kc W, Wu X, Briseno CG, et al. Heme-mediated SPI-C induction promotes monocyte differentiation into iron-recycling macrophages. Cell (2014) 156:1223-34. doi:10.1016/j.cell.2014.01.069

229. Xue J, Schmidt SV, Sander J, Draffehn A, Krebs W, Quester I, et al. Transcriptomebased network analysis reveals a spectrum model of human macrophage activation. Immunity (2014) 40:274-88. doi:10.1016/j.immuni.2014.01.006

230. Schroder K, Irvine KM, Taylor MS, Bokil NJ, Le Cao KA, Masterman KA, et al. Conservation and divergence in toll-like receptor 4-regulated gene expression in primary human versus mouse macrophages. Proc Natl Acad Sci U S A (2012) 109:E944-53. doi:10.1073/pnas.1110156109

231. Ajami B, Bennett JL, Krieger C, McNagny KM, Rossi FM. Infiltrating monocytes trigger EAE progression, but do not contribute to the resident microglia pool. Nat Neurosci (2011) 14:1142-9. doi:10.1038/nn.2887

232. Segura E, Amigorena S. Inflammatory dendritic cells in mice and humans. Trends Immunol (2013) 34:440-5. doi:10.1016/j.it.2013.06.001

233. Zhan Y, Xu Y, Seah S, Brady JL, Carrington EM, Cheers C, et al. Resident and monocyte-derived dendritic cells become dominant IL-12 producers under different conditions and signaling pathways. J Immunol (2010) 185:2125-33. doi:10.4049/jimmunol.0903793

234. Fei M, Bhatia S, Oriss TB, Yarlagadda M, Khare A, Akira S, et al. TNF-alpha from inflammatory dendritic cells (DCs) regulates lung IL-17A/IL-5 levels and neutrophilia versus eosinophilia during persistent fungal infection. Proc Natl Acad Sci U S A (2011) 108:5360-5. doi:10.1073/pnas.1015476108

235. Ikarashi M, Nakashima H, Kinoshita M, Sato A, Nakashima M, Miyazaki $\mathrm{H}$, et al. Distinct development and functions of resident and recruited liver Kupffer cells/macrophages. J Leukoc Biol (2013) 94:1325-36. doi:10.1189/ jlb.0313144

236. Lowes MA, Chamian F, Abello MV, Fuentes-Duculan J, Lin SL, Nussbaum R, et al. Increase in TNF-alpha and inducible nitric oxide synthase-expressing dendritic cells in psoriasis and reduction with efalizumab (anti-CD11a). Proc Natl Acad Sci U S A (2005) 102:19057-62. doi:10.1073/pnas.0509736102

237. Fujita H, Shemer A, Suarez-Farinas M, Johnson-Huang LM, Tintle S, Cardinale I, et al. Lesional dendritic cells in patients with chronic atopic dermatitis and psoriasis exhibit parallel ability to activate T-cell subsets. J Allergy Clin Immunol (2011) 128:e1-12. doi:10.1016/j.jaci.2011.05.016

238. Reynolds G, Gibbon JR, Pratt AG, Wood MJ, Coady D, Raftery G, et al. Synovial CD4+ T-cell-derived GM-CSF supports the differentiation of an inflammatory dendritic cell population in rheumatoid arthritis. Ann Rheum Dis (2015). doi:10.1136/annrheumdis-2014-206578

Conflict of Interest Statement: The authors declare that the research was conducted in the absence of any commercial or financial relationships that could be construed as a potential conflict of interest.

Copyright (C) 2015 Reynolds and Haniffa. This is an open-access article distributed under the terms of the Creative Commons Attribution License (CC BY). The use, distribution or reproduction in other forums is permitted, provided the original author(s) or licensor are credited and that the original publication in this journal is cited, in accordance with accepted academic practice. No use, distribution or reproduction is permitted which does not comply with these terms. 